\title{
Sepulchral use of caves in Lusatian culture: Evidence from the Sąspówka Valley in the Polish Jura
}

\author{
Pohřební využití jeskyní v lužické kultuře: \\ nálezy z údolí Sąspówka v Polské Juře
}

\author{
Małgorzata Kot - Grzegorz Czajka - Elżbieta Jaskulska - \\ Marcin Szeliga - Bartosz Kontny - Adrian Marciszak - \\ Michał Mazur - Michał Wojenka
}

\begin{abstract}
Funeral and ritual practices in cave sites during the Late Bronze Age and Early Iron Age have been recognised in multiple sites south of the Carpathians. This paper presents the first evidence for the funeral and ritual use of cave sites with such chronology north of the Carpathians. Unburned human remains dated to Ha B and Ha C/D have been identified in two cave sites (Zbójecka Cave and Bramka Rockshelter) located $500 \mathrm{~m}$ apart, in the Polish Jura. Additionally, a pottery deposit dated to Ha B2-C has been found in a third cave (Ciasna Cave) situated near the aforementioned sites. The paper analyses these finds in the context of the local Lusatian culture settlement and the already recognised traces of Lusatian cave site use in the studied karstic region. The results give ground to search for more evidence of ritual cave use in the Late Bronze Age and Early Iron Age.

Polish Jura - Late Bronze Age - Early Iron Age - cave sites - burial

V mnoha jeskynních lokalitách jižně od Karpat byly rozpoznány doklady pohřebních a rituálních praktik z pozdní doby bronzové a starši doby železné. Tento článek predstavuje první důkaz takového jednání severně od Karpat. Nespálené lidské ostatky datované do Ha B a Ha C/D byly identifikovány ve dvou lokalitách Polské Jury (Zbójecka jeskyně a prevevis Bramka), vzdálených 500 m od sebe. Kromě toho bylo ve třetí jeskyni (jeskyně Ciasna), která se nacházi pobliž jmenovaných, nalezen depot keramiky datované do Ha B2-C. Př́spěvek tyto nálezy začleňuje do kontextu místního osídlení lužické kultury a již známých dokladů využití jeskynních lokalit ve zkoumaném krasovém regionu. Výsledky poskytují podklad pro identifikaci dalších důkazů rituálního využití jeskyní v pravěku.
\end{abstract}

Polská Jura - pozdní doba bronzová - starší doba železná - jeskyně - pohřeb

\section{Introduction}

The funeral and ritual use of cave sites is well attested throughout Prehistory. It is an especially well-studied phenomenon for Stone Age (Bergsvik - Skeates 2012; Moyes 2014; Orschiedt 2012; Riel-Salvatore - Gravel-Miguel 2013; Peterson 2019). During the Bronze Age and Early Iron Age, it is confirmed in several regions in Europe (Büster - Warmenbol Mlekuž 2019; Dowd 2015). In Central Europe human remains dated to Bronze Age and Early Iron Age have been found in several caves in Slovakia, Czechia, Austria and SE Germany (Galik 1998; Orschiedt 2012; Parzinger - Nekvasil - Barth 1995; Peša 2006). Still, a current state of research seems to be unsatisfactory. It is due mainly to the poor state of preservation of the primary contexts in Holocene cave sediments and lack of direct radiocarbon dating of the human remains. In most sites, human and animal activities and erosional processes caused a postdepositional mixing of the Holocene humus layers, 
including artefacts and human remains. Single cave sites with stratified Holocene layers can be found (e.g., Wilczyński et al. 2020; Krajcarz et al. 2020; O’Regan et al. 2020 for further discussion).

In Poland, most caves can be found in the karstic region of the Cracow Upland, where over 100 cave sites have been excavated so far. Although their excavations started as early as 1870 s, for most of their research history the Holocene-era cave deposits were seldom a subject of scientific interest. During archaeological campaigns led by Jan Zawisza, Ferdinand Römer or Godfryd Ossowski in the last three decades of the $19^{\text {th }} \mathrm{c}$., the attention was paid mostly to Pleistocene-era layers. The exception were only the excavations of Stanisław Jan Czarnowski, which were carried out mostly in the 1900s and 1910s and encompassed more than 30 caves and rockshelters. Unfortunately, while Czarnowski's interest was focussed mainly on the content of Holocene sediments, nowadays the results of his excavations are of restricted value due to the lack of stratigraphic and planigrafic information. In the next decades of archaeological prospection it was again the Pleistocene-era in the limelight of cave researchers (for further discussion, see Partyka 1992; Lech 2001; Lech-Partyka 2006; Wojenka 2012). As a consequence the Holocene human occupation in caves is still poorly studied.

Even though a substantial amount of human remains has been reported throughout the last 150 years of cave studies in Poland, until recently when their chronological position remained undetermined due to the lack of direct radiocarbon datings. It was a case of multiple human remains of unknown chronology found in Zbójecka Cave by Ferdinand Römer (1883) or human skulls found by S. J. Czarnowski in several sites, i.a. in Oborzysko Wielkie by Ciemna Cave or Okopy Wielka Dolna Cave in Ojców (Czarnowski 1903; 1904a; 1909). The only exception and contextualised finding was a discovery of a human skull made by Czarnowski in a small niche inside Borsucza Cave in Ojców, which was accompanied by the pottery vessel attributed to the Pleszów Group of Lengyel-Polgár cycle (Czarnowski 1901). Due to the context of the finding, the skull has been traditionally attributed to the Neolithic period (Rook 1980). As a consequence, for a long time the only confirmed Holocene human remains from the caves in question could be attributed to the Neolithic.

In recent years, a new approach toward reconstructing the original archaeological context within the Holocene cave sediments through multi-proxy analyses can be observed in cave archaeology (Gutiérrez Cuenca et al. 2017; Kot et al. 2019; Ledogar et al. 2019; Svoboda et al. 2004; Wilczyński et al. 2012). It is based on analysing single artefacts and human remains using different direct analytical methods, including dating (e.g., Kontny et al. 2021). Direct dating of human remains from cave sites allowed to confirm the presence of Eneolithic funeral practices on the cave sites such as Tunel Wielki Cave (Wojenka et al. 2017) or Ciemna Cave (Valde-Nowak - Stefański - Szczepanek 2018), but also revealed some new cave funeral practices occurring in later periods. Radiocarbon dating allowed identifying a $17^{\text {th }}$-century unusual child burial in Tunel Wielki Cave (Wojenka et al. 2021).

The recent paper follows the same approach. Its principal goal is to present the results or re-analyses of the assemblages from three cave sites located in the same karstic valley, i.e. Zbójecka Cave, Bramka Rockshelter and Ciasna Cave. The analysis of the artefacts and skeletal remains found at these sites constitutes the first evidence of the ritual and funeral use of cave sites by the Lusatian communities in the Late Bronze Age and Early Iron Age. These results significantly alter the existing picture of the ways in which caves and rockshelters were used by the Late Bronze Age and Early Iron Age populations north to the Carpathians. 
Until recently, the Cracow Upland region, including the karstic area of the Ojców Jura, was seen primarily as an area of systematic expeditions and penetration by Lusatian culture communities, not forming part of that culture's principal settlement oikumene concentrated in the western part of Lesser Poland (Rydzewski 2006, 479). Discovered relics of intensive and long-lasting Lusatian settlement in Modlnica and Modlniczka (Byrska-FudaliPrzybyła 2012; Dzieggielewski 2015a) altered that picture, at least in case of the region's southern part. However, the northern part of the Ojców Jura, characterised by karstic landforms and the presence of numerous caves, remains an exceptionally enigmatic area during the Late Bronze Age and Early Iron Age settlement.

Many of the traces of Lusatian culture settlement discovered in the Cracow Upland are cave sites. A dense concentration of these is found in the Prądnik and Sąspówka Valleys (fig. 1), although the majority are single finding spots, represented by a few of vessel fragments, or even single shards. In only a few caves (such as Wierzchowska Górna and Okopy Wielka Dolna in Ojców) larger quantities of Lusatian artefacts have been found, mainly ceramics. These indicate that the caves were used by people of the Lusatian culture as provisional camps or shelters, probably maintained for only a short time (e.g., Rydzewski 2006, 484), apparently associated with temporary economic activity and with defensive and military uses (e.g., at the time of the Scythian invasions; see Czarnowski 1924, 22). It was believed until recently that such activities reflected a full range of use of the caves by Lusatian communities in these areas. However, there was no evidence of ritual, symbolic or funeral activities (Gedl 1975, 82; Jędrysik 2016, 61) as had been documented in places such as the Czech Republic, Slovakia and south-eastern Germany (an example being the Bärenkeller Cave; Peša 2006, 71; Walter 1985).

Open sites in this area are extremely sporadic and have undergone minimal archaeological prospection; they are represented mainly by isolated finds of single artefacts and single graves (Rydzewski 2006, fig. 1). This made all the more surprising the discovery by the confluence of the Prądnik and the Sąspówka (fig. 1), under the remains of the mediaeval castle in Ojców, where relics of a settlement from the Early Iron Age (Ha C-D; Wojen$\mathrm{ka} 2016$ ) were found. Interestingly, the large quantity of burnt material discovered in the cultural layers associated with the Lusatian phase of settlement, as well as the discovery of two Scythian arrowheads (one of bronze and one of bone; Wojenka 2016, 221-222, fig. 14; see also Chochorowski 2014, 33, fig. 19) suggest that the settlement may have been destroyed as a result of invasion.

To date, no large Lusatian culture cemetery has been recorded in the Prądnik and Sąspówka Valleys or in their vicinity. A single cremation grave has been found at the site of an early mediaeval fortified settlement at Sokole Skały (also known as Będkowice site 2 'Sokolica'); it may be dated to the later part of the Early Iron Age (Stotyhwo 1922; Jędrysik 2016, 66-70; 2018, 66). Directly opposite on the other side of the Będkówka Valley a skeletal grave was discovered during earthworks (Będkowice site 34); accompanying ceramics indicate that it can be dated to a slightly earlier period, Ha C (Rydzewski 2006, 476; Jędrysik 2016, 73-75). A similar find was made in Sąspów (site 104). That grave contained, among other items, ceramic material in the style of the Tarnobrzeg group of the Lusatian culture, which is to be interpreted as cultural influence on the local Upper Silesian-Lesser Poland group. The find is dated to the period Ha D (Liwoch - Wójcik Wróbel 2015, 176-177; cf. also Dzięgielewski - Godlewski 2009). 


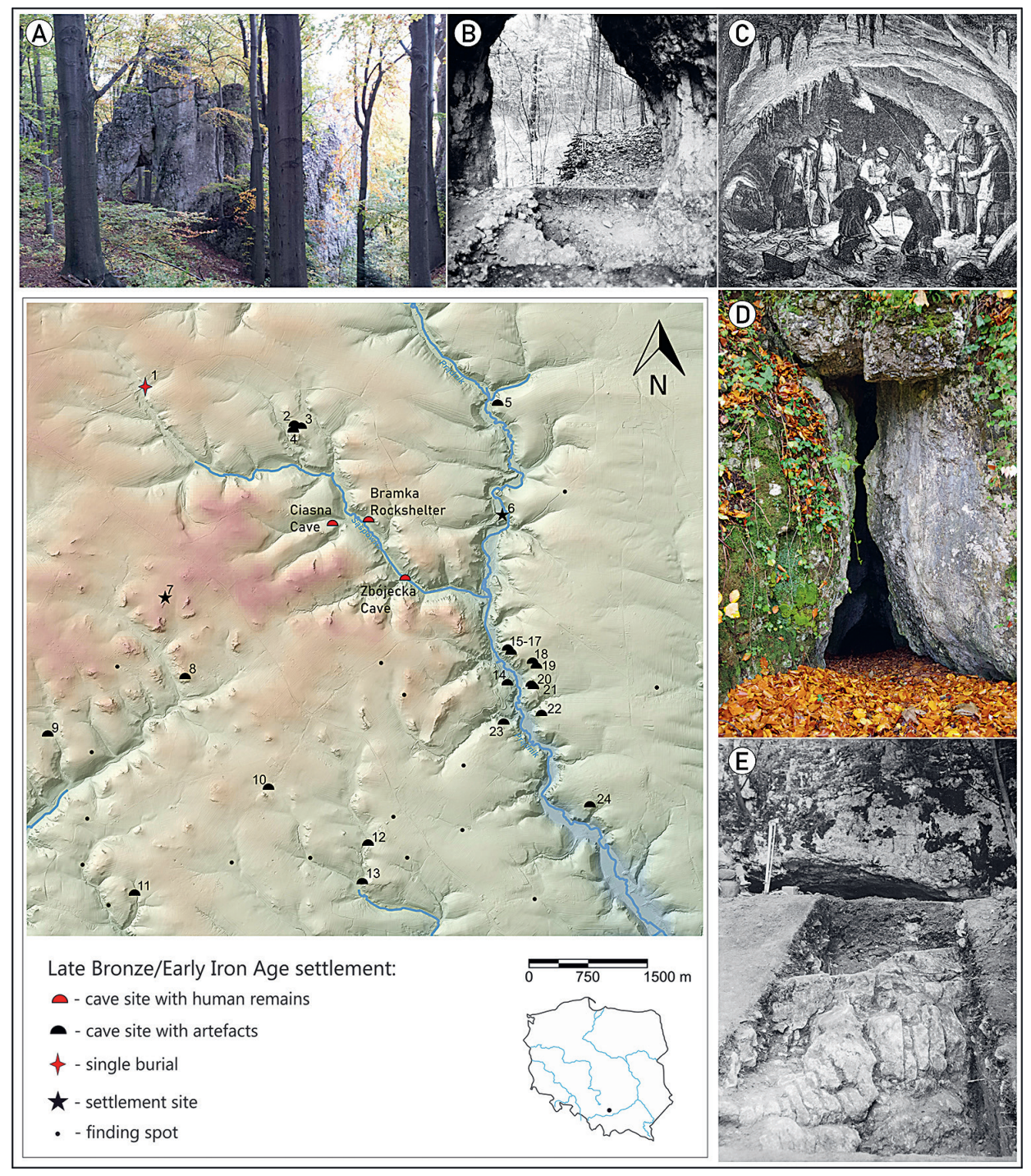

Fig. 1. Location of the described Late Bronze/Early Iron Age cave sites cave sites. 1 Sąspów site 104 (Liwoch 2005); 2 Rockshelter above Niedostępna Cave, Sąspów site 5 (Kot et al. 2020); 3 Tunel Wielki Cave, Sąspów site 6 (Kot et al. 2020); 4 Rockshelter under Tunel Wielki, Sąspów site 7 (Kot et al. 2020); 5 Nad Mosurem Starym Cave, Skała site 1 (Rook 1980); 6 Ojców site 34 (Wojenka 2016); 7 Jerzmanowice sites 14 \& 15 (Jędrysik 2016); 8 Nietoperzowa Cave, Jerzmanowice site 1 (Czarnowski 1910, 6-12); 9 Dziewicza Cave, Łazy site 24 (Jędrysik 2016); 10 Bębłowskie Dolne Rockshelter, Bębło site 1 (Rook 1963); 11 Wysoka Cave, Wielka Wieś site 1 (Czarnowki 1904b, 136-139); 12 Wierzchowska Górna Cave, Wierzchowie site 2 (Ossowski 1885b; 1886, 13-31); 13 Mamutowa Cave, Wierzchowie site 1 (Zawisza 1874; Kowalski 1967); 14 Nad Jabłońskim Rockshelter, Prądnik Korzkiewski site 1 (Czarnowski 1904b, 141-142, pl. VII: 1-2; Durczewski 1948a); 15 Ciemna Cave, Ojców site 18 (Czarnowski 1924, 4-21); 16 Pod Rękawicą Rockshelter, Ojców site 17 (Czarnowski 1924, 21-22); 17 Oborzysko Małe Cave (Czarnowski 1924, 22-23; Rook 1964); 18 Okopy Wielka Dolna Cave, Ojców site 3 (Mycielska - Rook 1965); 19 Rockshelter under Okopy/Główne w Okopach, Ojców site 4 (Czarnowski 1902, 440-441); 20 Dolne Zachodnie Rockshelter in Góra Koronna, Ojców site 12 (Czarnowski 1924, 23-24); 21 Ojców site 14, gm. Skała, Jaskinia nad Malarzówką Średnia/Główna w Kopcowej Górze (Czarnowski 1911, 8-16); 22 Upper Ogrojec Cave, Maszyce site 12 (Czarnowski 1914, 34-47); 23 Duża/Potrójna Cave in Korytania gorge, Ojców site 8 (Czarnowski 1904b, 125-136); 24 Maszycka Cave, Maszyce site 10 (Ossowski 1884, 70-85; 1885a); A - Bramka Rockshelter, recent view from the northern side; B - Bramka Rockshelter during fieldwork in 1973 conducted by W. Chmielewski - a child's burial was found in the vicinity of the large stone visible in the left side of the trench; C - first archaeological fieldwork in Zbójecka Cave conducted by Jan Zawisza (Olszyński 1871, 373); D - Entrance to Zbójecka Cave, recent view; E - Southern entrance to Ciasna Cave during fieldwork conducted by W. Chmielewski in 1969/70. 


\section{Methods and materials}

\section{Human remains}

Human remains were discovered at two of the analysed sites: Zbójecka Cave and Bramka Rockshelter. Identification of their human origin was performed by standard macroscopic analysis. However, in the case of the remains of the metatarsal from Bramka, the reliability of the assessment is reduced due to the presumed young age-at-death of the individual, in whom the full morphological characteristics of the bone had not developed. In the case of Zbójecka Cave, all identified remains belong to adult individuals (at least two individuals, based on presence of two left calcanei), making the species identification much more reliable.

\section{Radiocarbon dating}

To determine the age of the human remains found in Zbójecka Cave and Bramka Rockshelter, radiocarbon dating was required. Dates were obtained from three separate samples. A single metatarsal bone of a child from Bramka was dated by Oxford Laboratory. Two calcanei (heel bones) belonging to two separate individuals were dated by Poznan Radiocarbon Laboratory. All samples were dated using the collagen fraction. The laboratory procedures followed the widely approved protocols (Brock et al. 2010; GoslarCzernik - Goslar 2004). The results obtained were calibrated with OxCal v4.3.2 (Bronk Ramsey 2009; 2017; Bronk Ramsey - Scott - van der Plicht 2013).

\section{Archaeological artefacts}

Analysis was conducted on ceramic and metal artefacts from all of the mentioned sites. In the case of Ciasna Cave and Bramka Rockshelter, the analysis included artefacts obtained in excavations conducted by W. Chmielewski in the late 1960s and early 1970s (Chmielewski 1988), as well as materials obtained during verification of the previous research in 2017-2019.

In the case of Zbójecka Cave, analysis included complete set of materials from research conducted by F. Römer in 1879, currently held at the Archaeological Museum in Wrocław. Some of them were described by Römer $(1883 ; 1884)$, but the collection also consists of finds that have not previously been published, which are described in the present work. Because the presented materials were not previously published, they were subjected to extensive stylistic analysis, although the former investigations definitively excluded a connection with Lusatian culture. In addition, the files of M. Jahn (Szter 2011) were found to contain drawings of two artefacts from Römer's research in Zbójecka Cave, which Jahn catalogued during his visits to the museum in Wrocław (Szter 2011, 169-171). These include a bronze ring, unpublished by Römer, which is missing from the extant collection of artefacts. ${ }^{1}$ An analysis of this artefact based on Jahn's documentary drawing is presented in the text.

\footnotetext{
${ }^{1}$ The collection of archaeological artefacts from research by F. Römer, originally held at the Mineralogical Museum in Breslau (Wrocław), was partially dispersed during World War II. Many of the artefacts published by Römer are currently missing from the collection.
} 
The principal goal of the analyses was to identify materials that were unquestionably related to the Lusatian culture. The most numerous group consisted of ceramic materials, represented by 130 fragments from Ciasna Cave and six from Bramka Rockshelter. Analysis included their state of preservation and most important technological parameters (type and quantity of leaning admixture, character and colour of outer surfaces, method of working of the surface), as well as their formal and stylistic differences. Comparative material comes primarily from sites representing the Upper Silesian - Lesser Poland, Tarnobrzeg and Silesian groups of the Lusatian culture. This was dictated by the strong interaction that took place between these cultural units (Durczewski 1948a, 148-153; Dzięgielewski-Godlewski 2009; Rydzewski 2006, 479). The classification of ceramic vessels, used primarily the solutions presented developed in previous source analyses, particularly the typological classifications of Durczewski (1948a), Gediga and Józefowska (2018a), as well as the classification of materials from Iwanowice - Babia Góra site II by Suder (2000), the description of Silesian group of Lusatian culture materials by Gedl (1962), and the results of research at a cemetery site in Kietrz by the same author (1982a). Definitive typological identification of the analysed ceramic material was complicated due to its state of preservation, in particular the high degree of disintegration.

Planigraphic analysis was based on digitised archived documentary drawings and on measurements made using a tacheometer during verification of the previous research. The results were used to identify any clusters of materials of particular type (e.g., ceramic) or any correlations between particular artefacts. The periodisation of the Late Bronze Age and Early Iron Age followed Trachsel (2004).

\section{Results}

\section{Bramka Rockshelter}

Bramka Rockshelter is located on the northern slope of the Sąspówka Valley around $50 \mathrm{~m}$ above the bottom. The site consists a small rock window with entrances facing NW and SE, and is relatively small. Space beneath the rock does not exceed 30 square metres. The site was excavated in 1970 and 1973 by W. Chmielewski, who found traces of Early Mesolithic settlement. Apart from a rich stone assemblage found in the lower Holocene layer, called 5 (Madeyska 1988), an intentional burial containing child remains was found in the middle of the site. As the burial was found within the layer rich in Mesolithic stone artefacts, it was treated as a Mesolithic burial (Chmielewski 1988, 14). The human remains were briefly studied in the 1980s by Karol Piasecki, and the results of the analyses were presented in a master thesis (Pilcicka-Ciura 1995). Unfortunately, the human remains are currently missing, and have never been dated. The archaeological assemblage has never been published.

In 2017 a project was begun to re-examine the site stratigraphy and chronology. During a single fieldwork season, the old trenches were reopened and enlarged to collect laboratory samples. Additionally, the old backfill of the trenches was wet-sieved on $1 \mathrm{~mm}$ mesh. During the wet-sieving multiple archaeological artefacts were found, as well as single human remains.

The remains identified in the findings from Bramka Rockshelter are tentatively classified as human, as their size and state of preservation do not allow unconditional species 


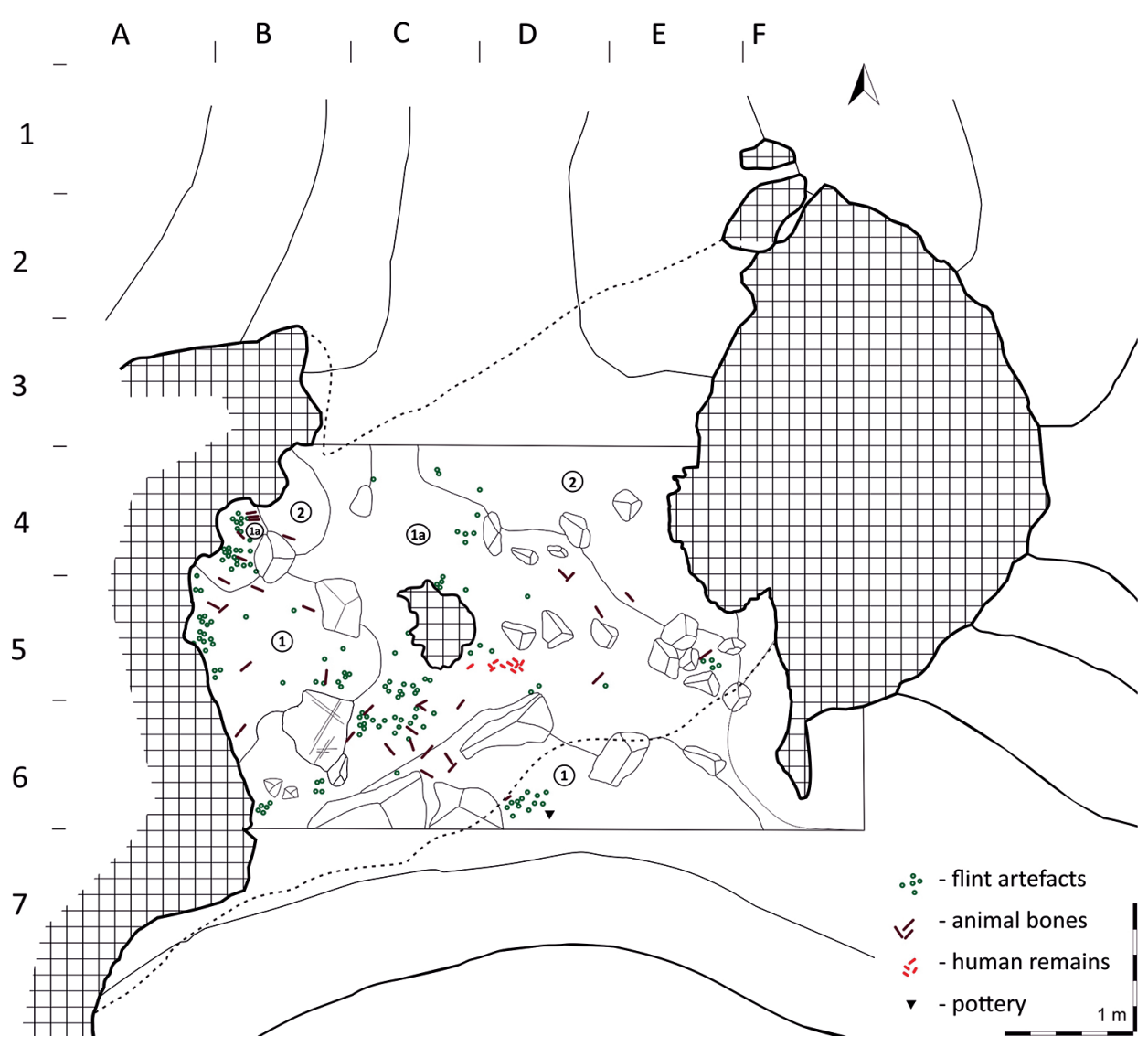

Fig. 2. Bramka Rockshelter. Plan of archaeological trenches at the depth where the child's burial was found during fieldwork in 1970 and 1973. Human remains are marked in red. (Drawn by M. Kot based on an original, unpublished field drawing.)

affiliation. The most probable human remains (Inv. $n^{\circ} \mathrm{FLO} / \mathrm{BH} 2 / 17$ ) have been identified as a complete metatarsal (without metaphysis) with a maximal diaphyseal length of $14.8 \mathrm{~mm}$, pointing to a young child whose age-at-death could not exceed 2 y.o. (based on the Department of Bioarchaeology juvenile osteological collection) and at minimum a newborn (Scheuer - Black 2000, 467). Some fragments are tentatively identified as a root of a permanent upper molar, which would point to an individual of at least 7-8 years, when the first permanent molar root usually develops.

Since the human remains found in 1973 are currently missing, we reproduce the following detailed description given by Pilcicka-Ciura (1995): 'Human bones found in sediments of layer no. 5 did not show signs of heat oxidation. The fossilisation of the bones was not significant. All the preserved skeletal fragments showed a similar preservation state, namely, apart from the similar fossilisation state, light brown colour and significant fragmentation. The largest fragments of the analysed material did not exceed a few centimetres in length. Based on morphological features the following elements were identified: 


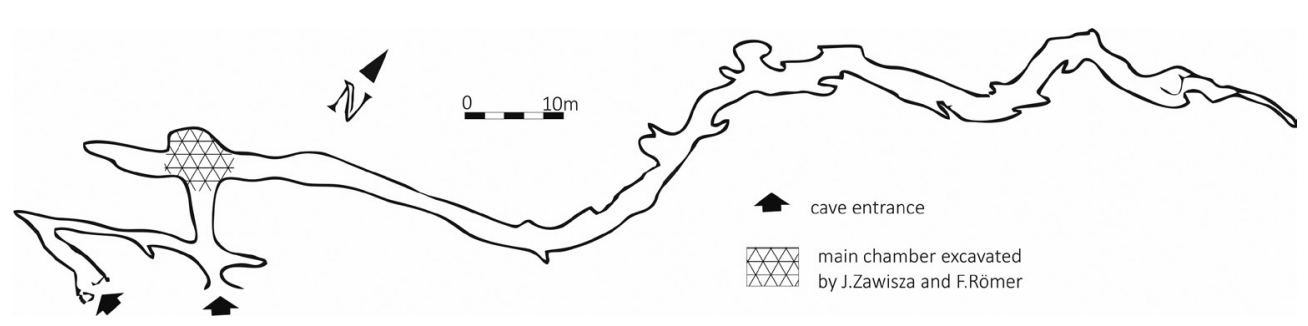

Fig. 3. Plan of Zbójecka Cave with the location of $19^{\text {th }}$ century fieldworks marked (drawn by M. Kot based on drawing made by Szelerewicz - Górny 1986).

fragments of the cranium, fragments of the femur, humerus and ribs. Analysis of the cranial obliteration and epiphyseal fusion allows the assumption that all the remains belong to one individual: a child of the Infants I stage (0-6 y.o.). In the burial (burial pit) vicinity, no material artefacts were discovered, which points to a lack of grave goods. The stratigraphic position of the burial is connected with the origin of layer no. 5. Final determination of the dating of the burial can be achieved by using new laboratory techniques for dating skeletal remains.' (English translation of the text: Pilcicka-Ciura 1995, 50)

Given the identical age estimation of the child remains found in 1973 and the bone found recently in the backfill of the trench from 1970-1973, it may be presumed that the wet-sieved bone came initially been from the child's burial located in the middle part of the site (fig. 2). The burial contained no grave goods. Therefore, no further archaeological interpretation could be conducted.

For this reason, the recently found bone was radiocarbon-dated. It was dated to 2731 $\pm 27 \mathrm{BP}$ (OxA-37734), which after calibration gives a chronology of 925-816 cal. BC (95.4\%), indicating the Late Bronze Age (Ha B) chronology of the burial. Therefore, we may assume that the burial was dug into the Early Holocene layer with rich Mesolithic assemblage. This gives us the assumption that the remains can be classified as a Lusatian culture skeleton burial of a child at a maximum of 2 y.o. placed in the rockshelter.

Interestingly, only scarce archaeological artefacts postdating the Mesolithic settlement episode were found at the site. Several atypical pottery pieces found in the 1970s and 2017 do not indicate any cultural affiliations. Considering the pottery's technological features (i.e., the admixture), it should be assumed that six pottery pieces can be attributed to the Late Bronze Age and the Lusatian culture, and may be contemporary to the child burial. Nonetheless chronological attribution of pottery based solely on technological features should be treated with caution.

Given that the fieldwork carried out in the 1970s covered most of the site's surface, it can be assumed that the cave was not used as a settlement site continuously or ephemerally by the Lusatian population. The site was used solely for sepulchral purposes.

\section{Zbójecka Cave}

Zbójecka Cave is located in the Jamki Gorge near its confluence with the Sąspówka Valley. The cave is situated $30 \mathrm{~m}$ above the bottom of the valley. The site has two small entrances which lead to the narrow corridors of a complex structure (fig. 3). Archaeological fieldwork was conducted in 1871 by J. Zawisza and in 1879 by F. Römer, but the cave was 
known even earlier. The name of the cave, which can be translated as 'Robbers' Cave', originated from the multiple human remains present at the site. Fig. $1 C$ shows a $19^{\text {th }}$-century visualisation of the first finds in the main chamber located $10 \mathrm{~m}$ behind the entrance. Römer also mentions the abundance of human remains found in Zbójecka Cave: 'Human skulls and bones were particularly abundant in this cave. Sometimes they were found at only a very small depth under the surface, and their state of preservation indicated no high antiquity; others lay deeper in the ground, and some of the bones and skulls were covered with a thick bed of stalagmite, and as they occurred together with ancient bronze implements, much higher antiquity is to be ascribed to them.' (Römer 1884, 15)

R. Virchov analysed in detail two skulls found by Römer in Zbójecka Cave (Römer $1884,33-34)$. One of them belonged to an adult, and the other to a young male individual. No information is provided as to whether Römer collected other human remains beside these skulls. Unfortunately, the described skulls are currently missing. However, in Römer's collection of animal bones currently held by the Department of Paleozoology at the University of Wrocław, a few human bones have been recognised. The identified human remains from Zbójecka Cave consist of two left calcanei, a left second metatarsal, right first metatarsal and right proximal phalanx of the first toe. All bones show adult dimensions and tissue structure. There is no evidence of recent epiphyseal fusion. According to these findings, the minimal number of individuals should be established as at least two adult individuals. The identified remains do not allow more detailed determination of age-atdeath or sex, although it is noteworthy that there is no significant evidence of degenerative process on the articular surfaces, and there are no pronounced muscle attachment sites. This observation may very tentatively point toward a young adult age-at-death assessment, which may be taken as corroborating the notes taken by Virchov. The amount of information gained from the identified bones is insufficient for a reliable and detailed age-at-death determination.

The two heel bones were radiocarbon-dated to $2500 \pm 30 \mathrm{BP}$ (Poz-114544) and 2490 $\pm 30 \mathrm{BP}$ (Poz-114543), which after calibration gives dates of 788-537 cal. BC (95.4\%) and 781-511 cal. BC (95.4\%). The results indicate that at least two human burials found by Römer can be dated to the Early Iron Age and were most probably related to the Lusatian culture. Interestingly, both dated remains show chronological consistency, indicating that perhaps the rest might have had a similar chronology.

Apart from human remains, Römer reported several artefacts found in the cave. Beside animal remains, he mentioned a bronze fibula (Römer 1884, pl. VI: 6) dated to the Late Roman period C3/D1 and D1, three amber beads (Römer 1884, pl. V: 3-4), several undetermined pottery sherds, a flint blade (Römer 1884, pl. 1: 8) and a stone polisher (Römer 1884, pl. V: 9). The artefacts are currently held at the Archaeological Museum in Wrocław. Interestingly, among the artefacts mentioned above, only the bronze fibula is present, but several other, unpublished artefacts are inscribed with the name 'Zbójecka Höhle'. Among the unpublished artefacts, notable are two clay spindle whorls (Römer 1883; 1884) and a single bronze ring. The ring is opened and has flattened endings. Its dimensions are $2.6 \mathrm{~cm}$ by $2.2 \mathrm{~cm}$; it is $0.3 \mathrm{~cm}$ thick in the middle part and $0.4 \mathrm{~cm}$ thick near the flattened endings (fig. 4: 2).

Römer also mentions some meticulously produced, dark grey or black clay spindle whorls, found in Zbójecka Cave and elsewhere, although he does not give their precise number or any information about their form (Römer 1884, 39). Two whorls can be linked 

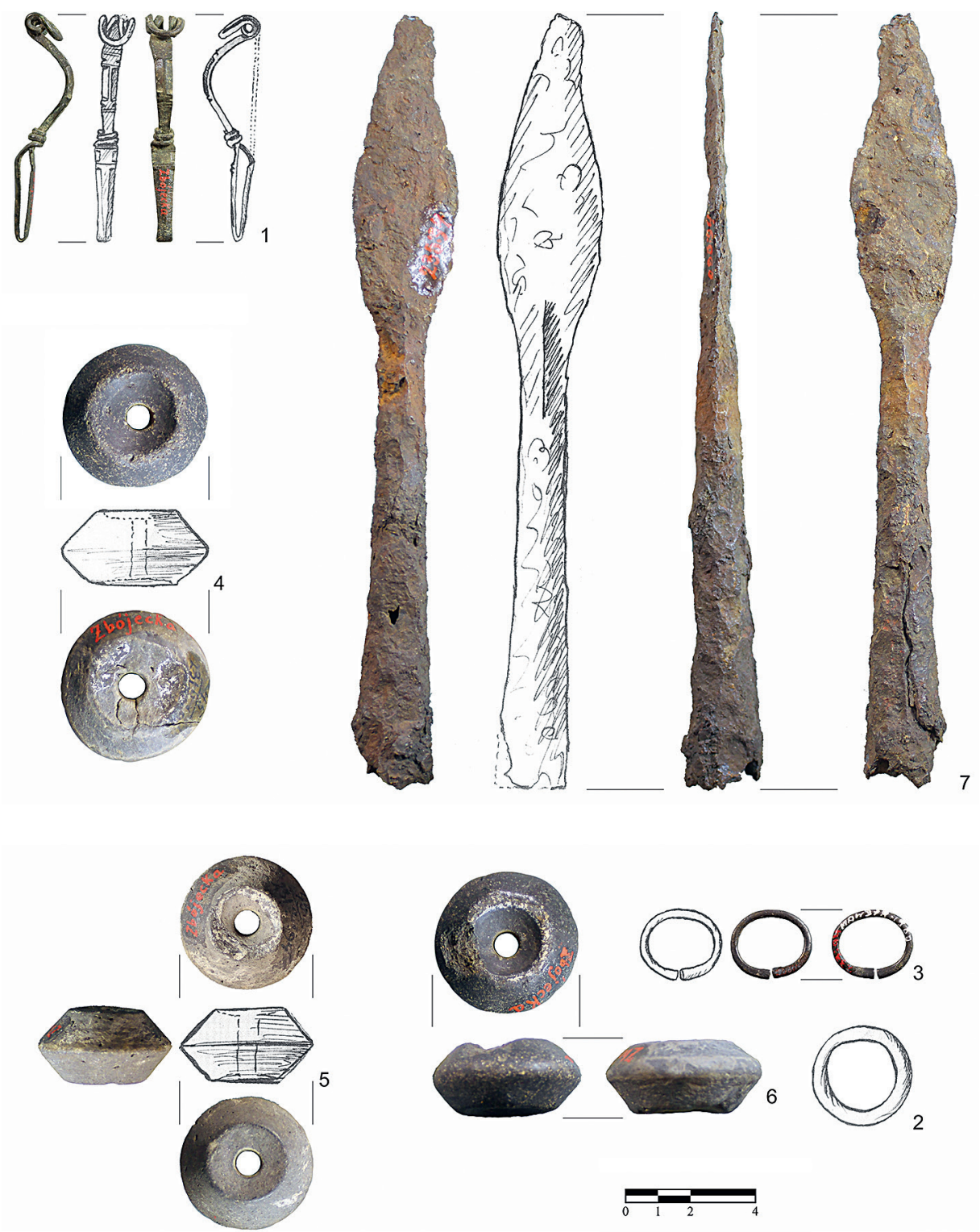

Fig. 4. Archaeological artefacts found in Zbójecka Cave by F. Römer in 1879. 1 - bronze fibula; 2-3 - bronze ring; 4-6 - clay spindle whorl (photo by M. Wojenka; drawn by M. Jahn).

to these finds thanks to sketches from the archive of Martin Jahn (fig. 4:4-5). Both carry the inventory number 231: 94 , and both are biconical, although one of them (black-grey, diameter $4 \mathrm{~cm}$, height $2.2 \mathrm{~cm}$ ) has a sharper-angled profile and more distinct hollows on the flat sides, while the other (black, diameter $4.3 \mathrm{~cm}$, height $2.2 \mathrm{~cm}$ ) is somewhat less sharp, with basin-like hollows and a slight rounding of the angle. Another similar spindle 
whorl, not documented previously by Jahn, with diameter $4.5 \mathrm{~cm}$ and height $2.4 \mathrm{~cm}$, chipped near the hole can be added to the set (fig. 4: 6). No decorations were found on any of the whorls, which is typical for artefacts of this type during the Roman period (Andrzejowski 1998, 79). All of them have biconical forms, classified as type P-2 according to Stasiak (1994, pl. 1, 2). These are, however, the most popular spindle whorl types in the Przeworsk culture, chronologically insensitive, also found in large numbers in other cultures, such as the Wielbark and Chernyakhov cultures (Magomedov 2015, fig. 1). The precision of the dating is not improved by the fact that in terms of colour, the clay from which the objects were made is similar to the vessels from the Younger and Late Roman periods. It is possible only to state in general terms that these are objects from the Roman period or the early Migration period.

Among the fine sandstone sharpening stones published by Römer, one specimen is ascribed to Zbójecka Cave (Römer 1884, pl. V: 9). This is, it would seem (the publication does not contain a scale), a large specimen, fragmentarily preserved, having in its central part a groove presumably resulting from use. Similar features have often been found on sharpening stones from the protohistoric period. However, the artefact has not survived, and its identification cannot therefore be verified.

An amber bead (Römer 1884, pl. V: 3) may theoretically be assigned to group XXX, type 389 according to M. Tempelmann-Maczyńska (1985, 67, tab. 5, pl. 15), which covers the whole of the Roman period and the early Migration period. It is not certain whether this identification is correct, however, as the specimen is not cylindrical, this being one of the distinguishing features of the aforementioned type (in profile the object is seen to be of non-uniform thickness).

The bronze 'ring' at inventory number 233: 94, preserved in the Wrocław collections (inv. no. MAW/2/379), is also shown on a sketch by M. Jahn (fig. 4: 3), with a note casting doubt on its inclusion in the set of artefacts connected with the Roman period ('wohl nicht Kaiserztl.'). It is true that similar specimens are not found among known rings from the Roman period, whether local or imported from the Empire (cf. Beckmann 1969, pl. 1-2). However, it is hard to rule out entirely the possibility that the artefact is related to other objects from late antiquity, as it has a very similar shape to the bracelets with broad endings (German Kolbenarmringen) considered a marker of high position in Germanic society. Taken from distant parts of Asia, known among the Black Sea Sarmatians as early as the first century CE, they became extremely popular among the Germanic elites from the second half of the third century until the late Migration period ${ }^{2}$ (cf. Skripkin 2003, 15, fig. 2; Quast 2013, 175-185). They are also found in Czech caves from the end of the Roman period and the early Migration period - see the bronze specimen from the Čertova ruka massif (Jiř́k 2008, 171, fig. 15: 22) - and in sacrificial deposits - see Hřensko (Jiř́k 2008, 174, fig. 17). Thus, despite Jahn's scepticism, it is not possible to exclude entirely a temporal connection between the discussed ring and the use of Zbójecka Cave around the end of Roman times and the start of the Migration period. It may be hypothesised to be a miniaturised image of a known symbol, used differently than the original.

\footnotetext{
${ }^{2}$ In the fourth century they were also made in the Empire, and one of the marks of the barbarisation of the Roman army was the custom of paying soldiers ' wages in broad-ended rings as well as in coins (Quast 2013, 181-185).
} 
A bronze fibula (Römer 1884, 39, pl. VI: 6), which survives in the Wrocław collections, and was also sketched by M. Jahn (fig. 4: 1), should be assigned to the type Almgren 158 (Almgren 1923). I. Jakubczyk ascribed it to his own Ojców 3 variant, ${ }^{3}$ dated to phases C3/ D1-D1 (Jakubczyk 2014, 133-134, fig. 4), ${ }^{4}$ that is, from the end of the third quarter of the fourth century to the start of the fifth century. This is a form encountered mainly in the southern reaches of the Przeworsk culture, especially in the caves of the Kraków-Częstochowa Jura (Jakubczyk 2014, 134, map 10), and was made locally.

A spear is shown on a page from the archive of Martin Jahn (fig. 4: 7), who clearly sketched it from the original, which was held at the Wrocław museum in the university collection: 'Mus. Breslau (Univers. Slg.)'. Based on that sketch, the artefact can be assigned to Zbójecka Cave. The object still survives in the Wrocław collections. It has reconstructed length (G) c. $24 \mathrm{~cm}$ (preserved $23.2 \mathrm{~cm}$ ), socket length $(\mathrm{T}) 14 \mathrm{~cm}$, reconstructed blade length (L) c. $10 \mathrm{~cm}$, blade width (A) $3.1 \mathrm{~cm}$, distance along the blade from the maximum width to the tip (Q) c. $6 \mathrm{~cm}$ (reconstructed), reconstructed outer socket diameter $2.3 \mathrm{~cm}$, stem shape T2, its cross-section PT1, blade cross-section PL B1/2, cross-section at socketblade boundary PTL 9/10, coefficients $\mathrm{T} / \mathrm{G}=0.58, \mathrm{~A} / \mathrm{L}=0.31, \mathrm{Q} / \mathrm{L}=0.6$. It should be assigned to type XII.1 according to Kaczanowski, which is dated to phase B2b and - especially - the B2/C1 boundary (Kaczanowski 1995, 22, pl. XX), meaning almost the whole second century CE except for its start. This is therefore not consistent with Jahn's suggestion: 'spät kann IV. Jahrh. sein.'

Jahn's archive also contains a sketch of another bronze 'ring', also with inventory number 233/94 (fig. 4: 2), which he described as 'vielleicht Schnallenrahmen des IV. Jahrh!'. It appears in fact to be the frame of a buckle of near-oval shape, slightly thicker on one side. Because of the absence of a spike and a possible ferrule, its typological classification cannot be unambiguously determined; it may be placed within types H25-28 according to R. Madyda-Legutko (1986, 67-68, pl. 20: 25-28) and dated to the early Migration period. Similar buckles are known from the area of the Chernyakhov culture and from the Pontic zone, where they are dated to the end of the late Roman period and subphase D1 of the Migration period (Tejral 1986, 192-194; Kontny - Savelâ 2006, 132-133). They are also encountered in Polabia and in Jutland (Schuster 2016, 57). All of the aforementioned forms close to type H25 were linked by J. Tejral to subphase D1 (Tejral 1992, fig. 3: 14, 17, 19; $7: 9,17)$, and this - namely, the last quarter of the fourth century and the start of the fifth century - is the correct dating for the specimen discussed here.

It can be stated in conclusion that Zbójecka Cave was used at least from the start of the younger Roman period (the second half of the second century CE), but most of the well-dated artefacts come from the end of the Roman period and the start of the early Migration period.

None of the known artefacts from Zbójecka Cave can therefore be dated with certainty to the Early Iron Age and cannot be treated as synchronous with the human remains.

\footnotetext{
3 This variant is characterised by a strip foot (wider than the bow), a triangular bow narrowing towards the foot, and extensive metopic decoration and polishing, especially on the foot (Jakubczyk 2014, 133-134, pl. XXI-XXII).

${ }^{4}$ Given erroneously in the publication as Ojców 2; the context makes clear that the Ojców 3 variant was intended (Jakubczyk 2014, 156).
} 


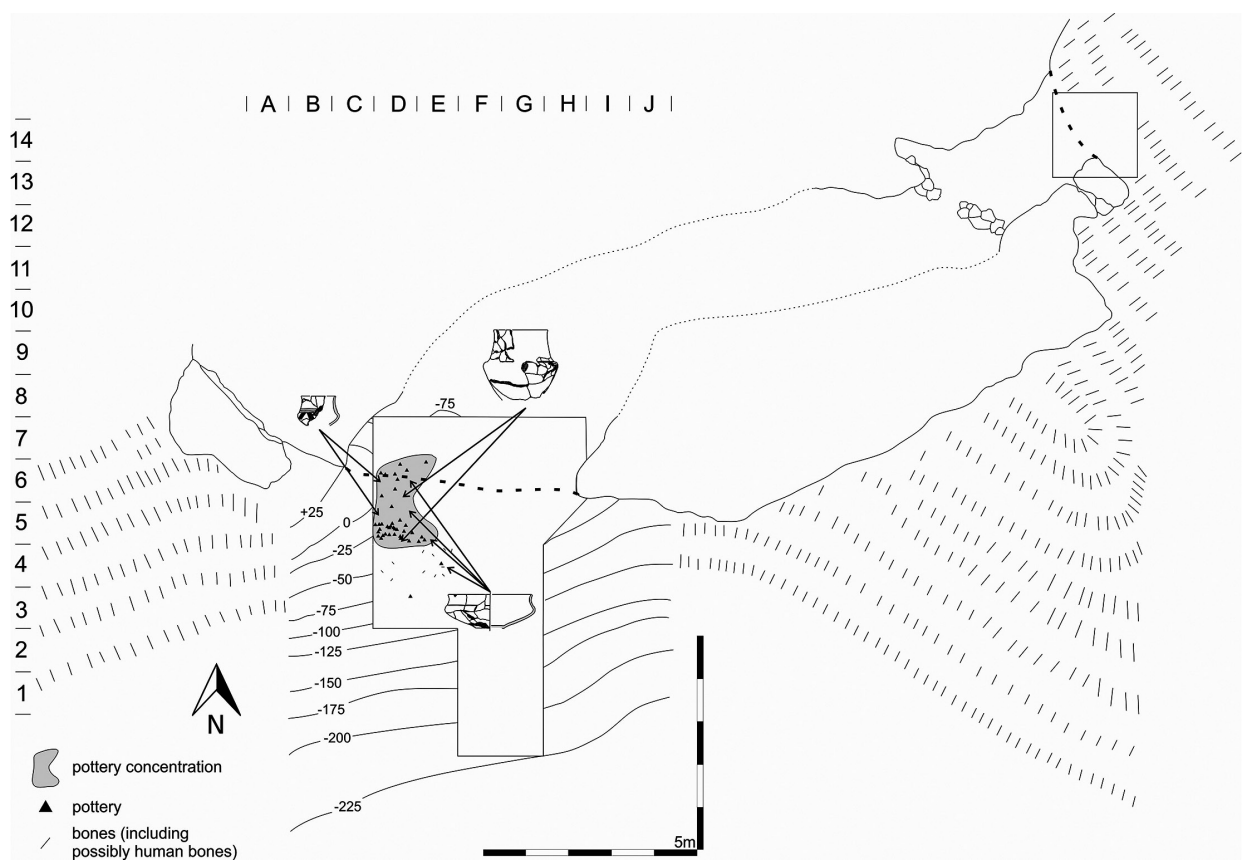

Fig. 5. Planigraphy of Lusatian pottery found during archaeological fieldwork conducted in Ciasna Cave in $1969 / 70$ by W. Chmielewski. The extent of the concentration of pottery pieces, which consisted of broken elements of only three vessels, is marked in grey (drawn by G. Czajka).

\section{Ciasna Cave}

Ciasna Cave is situated between two unnamed gorges, joining the Sąspówka Valley from the south, at an elevation of $448 \mathrm{~m}$ above sea level, approximately $94 \mathrm{~m}$ from the valley bottom. The cave is a tunnel with two entrances facing SW and E (fig. 5). Both entrances are very narrow, hence the cave's name, which means 'Tight Cave'. The SW entrance is wide, but is now no more than $70 \mathrm{~cm}$ high. The second entrance is completely filled, and is not accessible by humans. The cave is now completely filled with sediments. When the cave was excavated for the first time by W. Chmielewski in 1968-1969, it was still possible to crawl from one entrance to the other.

Fieldwork was conducted in front of both entrances (fig. 5), but the trench located in the SW entrance provided the most interesting results from this paper's perspective. In 1968, in the Holocene layer of black humus, approximately $50-80 \mathrm{~cm}$ under the surface, a concentration of black pottery was found. The excavator reported some four pieces of skull that were identified as 'probably human remains' found in the same trench, but the bone assemblage has been lost, and this information cannot now be confirmed. There is no information about burn marks on these bones.

Analysis of the ceramics found in the Holocene layers of Ciasna Cave has shown that the cluster contained fragments of three vessels from the Lusatian culture. This was at the southern entrance to the cave, under a colluvial embankment. After glueing and the making of reconstruction drawings, it was concluded that the pottery assemblage consists of only 
three forms. The first one is a large bowl with an S-shaped profile and an outward-curved rim, the rim diameter being slightly smaller than the maximum body diameter (fig. 6:2). ${ }^{5}$ The second form is a profiled vase with maximum breadth in the shoulder part, a slightly cylindrical neck, and a slightly outward-curved rim (fig. 6: 1). Both vessels have sparse ornamentation, limited to a single deep engraved line dividing the neck from the body. The last of the vessel forms discovered here is a miniature vase with somewhat richer ornamentation: three deep horizontal engraved lines dividing the neck from the body, and a rafter-like decoration (fig. 6: 3). For formal reasons these vessels are assigned to the Upper Silesian - Lesser Poland group of the Lusatian culture, but stylistically they are markedly similar to ceramic items from the Silesian group (Czajka 2019, 36-37).

All of the vessels were meticulously produced and were fired in a reductive atmosphere, as indicated by the grey colour of the fractured and inner surfaces. The black, sometimes shiny outer surface suggests that the potter applied additional treatments to improve the aesthetic quality of these vessels. Apart from similarities in the way the surfaces were made, surprising results are obtained from analysis of the mineral admixture used. The material of all of the vessels was leaned with sand and temper (which is typical for materials from the end of the Lusatian period) and with white crushed limestone (a sign of the use of local raw material in the clay mixture). However, the vessels exhibit different proportions (fig. 6) and densities of the admixed components. Temper is dominant in the material of the miniature vase, and fine and medium-grained white crushed limestone in the vase, while in the case of the bowl there is a slight predominance of the limestone over the sand admixture, in which isolated grains of gravel (no doubt added unintentionally) are also present.

The technological and stylistic similarities, and the results of planigraphic and comparative analysis, lead to the conclusion that this is a synchronous deposit, to be dated between Bronze Age period V and Ha C (Ha B2-C). The set is difficult to interpret, but the careful manufacture of the vessels and the their contemporary deposition in an inaccessible pla$\mathrm{ce}^{6}$ may suggest that they are remains of a destroyed cremation burial. This hypothesis is also supported by the composition of the described collection, which corresponds to sets of grave goods often found in this period: the large vase may have been an urn for ashes, the bowl may have served to cover it, and the miniature vessel may have been an accompanying votive offering. Inventories of the contents of graves from the Upper Silesian Lesser Poland group show that the placement of three vessels in a grave was a fairly widespread custom (Durczewski 1948a, 12). An additional argument for this interpretation is the information recorded in the field diary and field inventory of artefacts drawn up by W. Chmielewski, noting the finding at the place of the concentration of Lusatian ceramics (metres D4 and E4) of four 'probably human' skull fragments. Unfortunately, Chmielewski's note does not contain information on any traces of burning, which might be expected on the surface of these bones. These materials have been lost, and it is therefore not possible to re-analyse them to obtain confirmation of the above theory.

\footnotetext{
5 The maximum body diameter is $23.5 \mathrm{~cm}$, and the rim diameter is slightly smaller $(22 \mathrm{~cm})$. In later Lusatian ceramics this is a distinctive feature for the Early Iron Age (Dziegielewski 2015a, 80). An example of an analogous vessel is bowl N14 from grave 3760, found at a cemetery in Domasław, site 10/11/12 (Gediga - Józefowska 2018b, 430).

6 The cave is now around $50 \mathrm{~cm}$ high at its highest point, and the vessels were deposited at quite a shallow depth.
} 

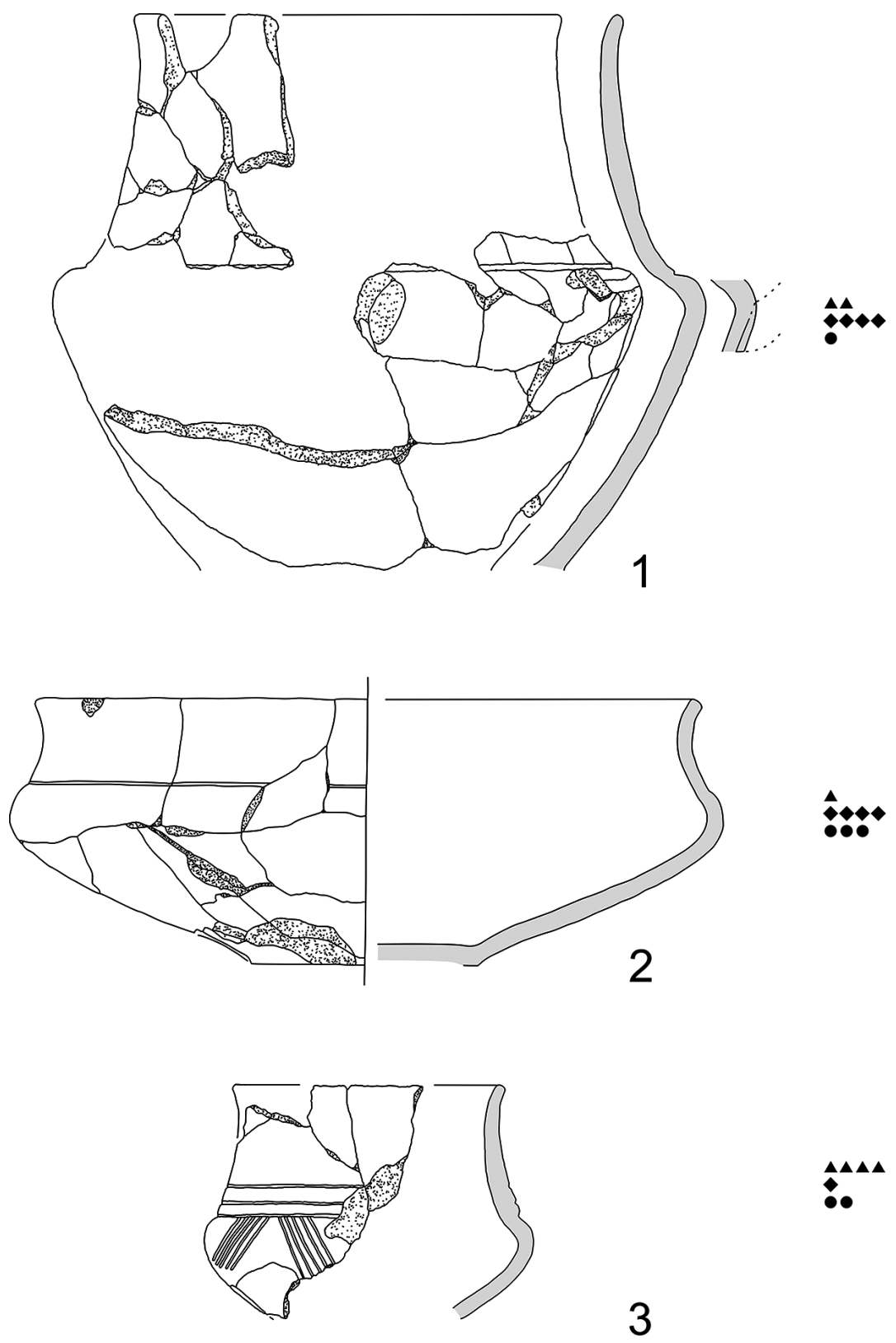

$\Delta$ temper

white crushed limestone

sand

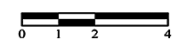

Fig. 6. Three Lusatian culture vessels found in Ciasna Cave and the schematic structure of the admixture in the clay. 1 - profiled vase; 2 - bowl with S-shaped profile; 3 - miniature vase (drawn by G. Czajka). 


\section{Discussion}

\section{Chronology}

The ceramic artefacts found in Ciasna Cave have features justifying their general dating to between Bronze Age period $\mathrm{V}$ and $\mathrm{Ha} \mathrm{C}$ or $\mathrm{Ha} \mathrm{C} / \mathrm{D}$. This corresponds very well with the overall range of radiocarbon dates obtained for the human remains from Zbójecka Cave and Bramka Rockshelter (fig. 7). The dating of the bone material from Bramka Rockshelter indicates an earlier chronology for that set, falling in the Late Bronze Age, and more precisely Ha B2-B3 (fig. 7). In turn, analysis of samples of bone material from Zbójecka Cave indicates a connection with the Early Iron Age, namely Ha C-D. The wide interval of dates for remains from Zbójecka Cave (fig. 7) is related to the 'Hallstatt plateau', that is, the flattening of the calibration curve between 750 and 420 BCE (for further discussion see Walanus - Goslar 2009). This phenomenon prevents the determination of precise dates within the given time interval.

The results obtained thus enable the described grave items and ceramic goods from caves in the Sąspówka Valley to be placed within a general period between 900 and 500 BCE, including the end of the Prokocim-Skotniki phase, the Iwanowice-Klin phase, and at least the beginning of the Biskupice-Tyniec phase of development of the Upper SilesianLesser Poland group of the Lusatian culture (cf. Gedl 1982b). These data not only agree with the continuity, confirmed by sources, of the settlement of the southern part of the Ojców Jura by representatives of the Lusatian culture at least from Bronze Age period V and Ha D (Dzięgielewski 2015a, 116-119; Rydzewski 2006, 485), but also document the durability of the tradition of sepulchral use of caves and rockshelters by local communities belonging to said culture.

\section{Cave site function}

From the bioarchaeological point of view, the scarce information about the in situ conditions of the analysed remains, together with their evident incompleteness, does not allow any further interpretation of the remains' original state. Therefore, discussion either they represent intentional burial or any other type of body (or bone) disposal is not possible based on current information. Still, the recent discovery should rather be considered an example of ritual use of these cave sites.

Within Central Europe, cave deposits containing human remains dated to the Late Bronze Age and Early Iron Age have already been identified in Slovakia, the Czech Republic, Austria and south-eastern Germany (Galik 1998; Peša 2006). One of the best studied is Býčí skála site in the Moravian Karst (Peter-Röcher 1998; Parzinger-Nekvasil-Barth 1995) which is interpreted as a sanctuary operating during Hallstatt period (Golec 2015). In the so-called Cave in der Breit the bones of children were found, accompanied by ceramic and bronze artefacts from the Urnfield culture (Stuhlfauth 1951, 142-145, cited in Peša 2006, 77, 110). At another burial site, in Fuchskirche Cave in Thuringia, a child burial was found in the context of Late Bronze Age/Early Iron Age pottery. Unfortunately the child's bones were not radiocarbon-dated, and a possible older, Neolithic dating is considered (Peša 2006, 72, 93; Walter 1985, 10-15). Beside the above mentioned sites, several other caves south to the Carpathians did contain human remains which can be attributed 


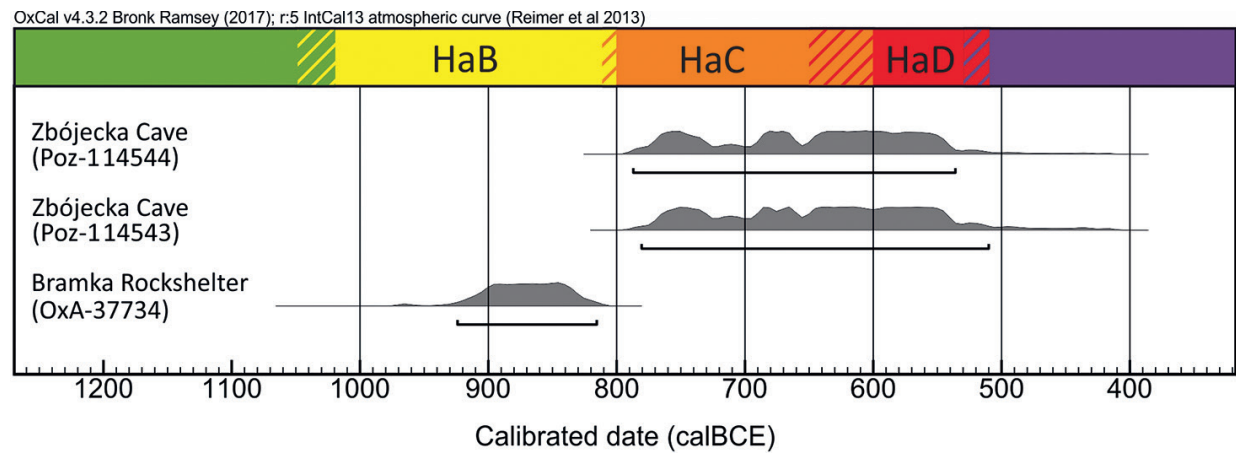

Fig. 7. Calibration curve of radiocarbon dates obtained for human remains from Bramka Rockshelter and Zbójecka Cave.

to the Late Bronze Age/Early Iron Age based on the accompanying artefacts (see Peša 2006 for further discussion) but their chronology should be treated with caution due to the lack of direct datings.

The deposit of ceramic vessels from Ciasna Cave (bowl, large vase and miniature vase) may be interpreted in two ways. In view of the mention in the field diary of the finding of four 'probably human' skull fragments at the same place as the concentration of Lusatian ceramics, it may be assumed that what was found there was a destroyed cremation burial or symbolic burial, containing few or no actual bones. In the Lusatian culture, symbolic burials not containing remains of the deceased, or having only a small quantity of remains, are known from sepulchral sites (Durczewski 1948a, 19; Gedl 1975, 84; Młodkowska-Przepiórowska 1995, 116; Zyzman 2009).

The deposit can also have another possible ritual interpretation; it may be seen as a votive deposit of ceramic vessels. Similar finds have been recorded in modern Czech Republic (Peša 2006, 90). An example is the single ceramic cup from the Lusatian culture discovered in situ in the vicinity of fragments of other vessels, under the small rock overhang known as Malá latrína, close to Branžež in the Czech Republic (Peša 2006, 62-63). To date there are no data on any contents of vessels deposited in such contexts; nevertheless, their placement in inaccessible spots indicates the exceptional nature of the deposit, which is probably of a sacral nature. A similar phenomenon of the depositing of vessels in cave sites in the same period is known from regions outside the extent of the Lusatian culture, for example in Kilgreany Cave in Ireland (Dowd 2015). Most often, however, cave sites are found containing deposits of bronze objects. One such site is Kallmünz in Bavaria, where a deposit of damaged bronze objects was discovered (Insoll et al. 2011, 398; Schauer 1981, 411, cited in Peša 2006, 100). Another example is cave no. 9 at Kyffhäuser, where approximately 20 bronze objects were found (Pě̌a 2006, 109-110).

In general the ritual use of caves in the Late Bronze Age and Early Iron Age has not previously been recognised in Poland. The results obtained in the Sąspówka Valley caves may change this view. Even if, due to the scattered and fragmentary nature of the bone material, it is not possible to confirm the sepulchral functions of the analysed sites, the results show that in the very small area of the Sąspówka Valley there is evidence of the ritual use of at least three cave sites. There are notable differences in the character of the use of 
these sites. While in Zbójecka Cave the remains of at least two adult individuals were deposited, in Bramka Rockshelter the burial consisted probably of remains of a small child (Infans I). In both cases there are no traces of cremation of the human remains. In the case of Bramka Rockshelter we can be certain that the human remains were not accompanied by grave goods.

In this context, the finds in Ciasna Cave differ from other sites, as three ceramic vessels, mostly preserved, were found there in a compact cluster. Particularly noteworthy is the absence of any other Lusatian material at that site, which indicates that the site was not in use, and that the deposit was synchronous. Results of stylistic and planigraphic analysis also confirm the contemporary deposition of the all three vessels, at the same time indicating the ritual nature of the deposit. Due to the absence of confirmed human remains in the vicinity of the vessels, it is not possible to determine whether this was a votive deposit of vessels, a symbolic burial, or, for example, a partial burial. It should be noted, however, that both forms of ritual use of caves have analogies in other areas where the Lusatian culture and related cultural groups were present in the period under discussion.

\section{Regional context}

Traces of the use of caves by the people of the Lusatian culture are known from at least three other cave sites in the Sąspówka Valley. A greater quantity of Lusatian material was found in Tunel Wielki Cave in the upper part of the Sąspówka Valley (fig. 1: 3), high above the bottom of Koziarnia Gorge, which joins that valley. In a trench at the entrance to the northern chamber of the cave, among heavily fragmented ceramic material, several Lusatian vessels were found, dated to the end of the Bronze Age or the Early Iron Age (Bronze Age period V - Ha C; Kot et al. 2020). The character of this material suggests that it was not deposited synchronously, and the site may have been used over a longer period and probably did not serve sacral purposes (Kot et al. 2020).

Single fragments of ceramics from the Lusatian culture were also found in two rockshelters located directly below Tunel Wielki Cave, called Pod Tunelem and Nad Jaskinią Niedostępną (fig. 1: 2, 4; Kot et al. 2020). The dating of both sites is analogous to that of Tunel Wielki Cave. The short distance between the sites is noteworthy; it may suggest that all three were likely used by the same groups of people at the same time.

Lusatian materials, predominantly ceramic artefacts, are also known from Nad Mosurem Starym Cave, Ciemna Cave, Dolne Zachodnie Rockshelter in Góra Koronna, Oborzysko Małe Rockshelter, Nad Jabłońskim Rockshelter, Okopy Wielka Dolna Cave, Upper in Ogrojec Cave, and also - outside the area of the Sąspówka and Prądnik Valleys - from Borsucza Cave in Podskalany, Mamutowa Cave and Wierzchowska Górna Cave (fig. 1; Jędrysik 2016, 38, 107-108, 115-116, 124-125, 140, 153; Durczewski 1948a, 113; Mycielska-Rook 1965, 155-159, 161-162, 166; Maczyńska-Rook 1972).

An open-air Lusatian settlement site was found recently at Ojców Castle at the conjunction of the Sąspówka and Prądnik Valleys (fig. 8). Under the mediaeval layers, a separate cultural layer ca. 20-50 cm thick, filled with Lusatian artefacts, was found on the castle hill. Within an area of 68 square metres, 36 post-holes and other pits were discovered, which is evidence of relatively stable settlement (Wojenka 2016, 220-221).

The characteristics of these features and of the associated cultural layer (which, importantly, is recorded within practically the whole cleared area) unquestionably indicate 


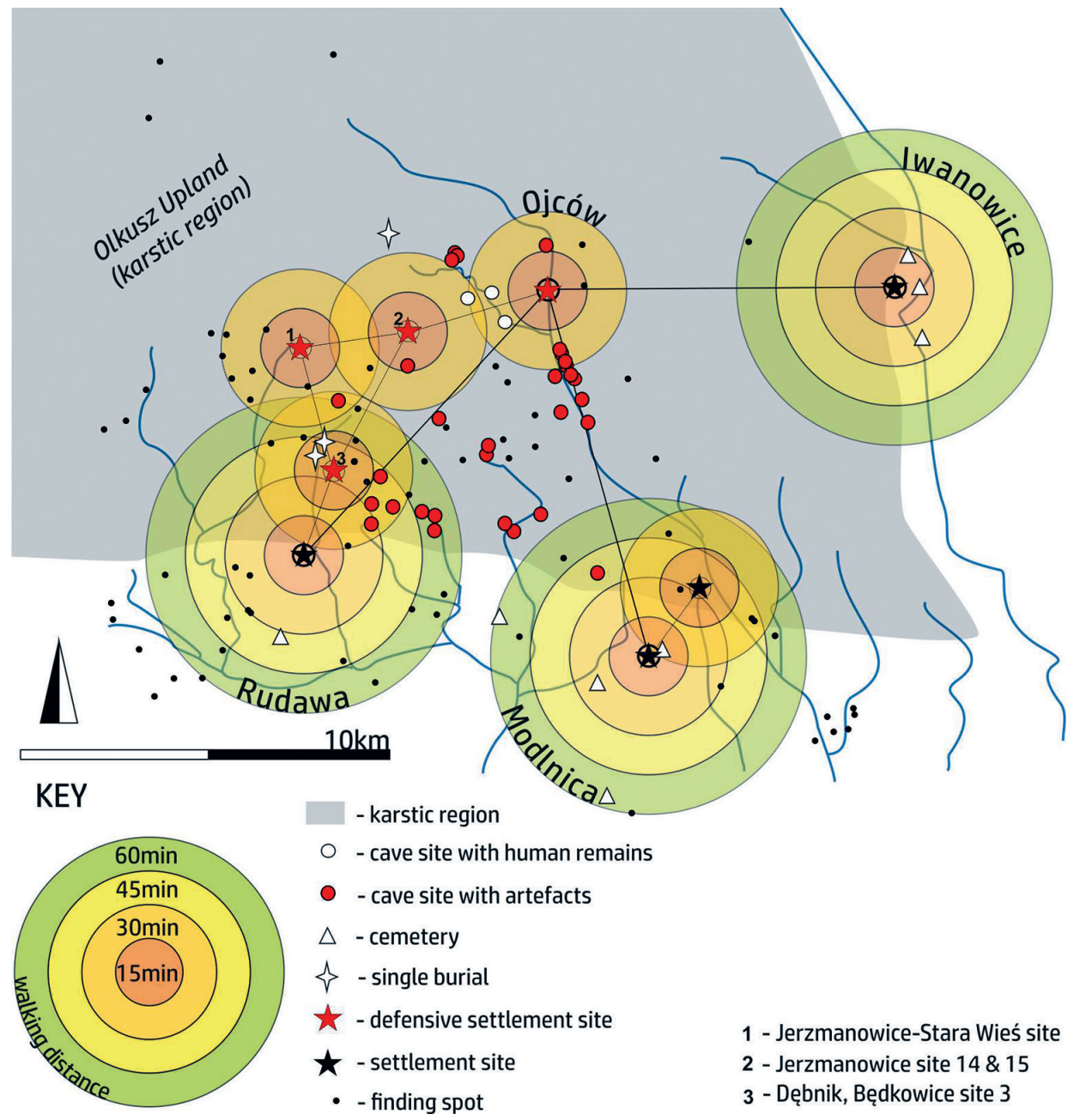

Fig. 8. Map showing sites with traces of Lusatian culture activity in the vicinity of the Sąspówka Valley, and walking distances between settlements. Walking distance was extrapolated to other settlement sites based on an analysis of the site in Modlnica (Korczyńska - Dzięgielewski 2015). The diagram shows that known Lusatian settlements in the Jura have defensive locations and are separated by smaller distances than settlements on the edges of the Jura. It is also noticeable that there are no cemeteries in the karstic region, although single burials occur, as well as a cave with human remains and traces of ritual activity.

that the place was occupied over a long period by an organised group of people. Admittedly, the 'Lusatian' archaeological features recorded at Ojców Castle are not distinguished by large dimensions or volumes of fill. However, account must be taken both of the craggy nature of the terrain on which that settlement was established, and of the intensity of the later mediaeval and modern settlement, which destroyed remains of earlier settlement processes.

Within the cultural layer and archaeological features from the Early Iron Age, a total of more than 3100 ceramic fragments were found. Although the collection consists pre- 
dominantly of nondiagnostic and damaged pieces, attention is drawn to the large number of relatively well-preserved fragments, enabling the reconstruction of the entire forms of vessels. Without entering into a detailed description of the discovered artefacts, which is not the purpose of this study, it is necessary to note their chronological coherence. Clearly dominant among the materials discovered here are fragments of vases (often with roughened bodies) and bowls (both with flat cut edges inclined outwards, and with edges curved inwards - which is a characteristic of ceramic deposits from the Early Iron Age). Ornamentation made by pressing with the fingers or fingernails is most common on the bodies and sometimes the edges of the vessels, as well as lines engraved on both the necks and bodies of vases. Particularly symptomatic is the discovery of fragments of plates decorated with fingernail grooves on the edge, which may (but need not) be an interpreted as practices typical of the latest parts of the Early Iron Age (cf., e.g., Dzięgielewski 2015b, 85). Another find attributable to this period is a fragment of the upper part of a vase with a black shiny surface decorated with horizontal lines at the base of the neck, and with 'pseudo-cord' ornamentation, and imprints of a twisted necklace forming a band of chevrons on the body (cf., e.g., Gawlik - Przybyta 2005, 324). Equally characteristic are the remains of pot-like vessels with decoration of finger or fingernail prints on an oblique strip. As noted previously in connection with the discovery in Sąspów (site 104) mentioned in present text (Liwoch - Wójcik - Wróbel 2015), this type of vessel decoration may carry eastern connotations, and if so, indicates a more recent provenance within the Early Iron Age (Ha D) (Dzięgielewski - Godlewski 2009).

The aforementioned stylistic features of the vessels discovered at Ojców Castle, in combination with other observed formal and morphological distinguishing features, are characteristic of the area of western Lesser Poland in the latest period of the functioning of the Lusatian cultural formation. It should also be noted that technological features of these ceramics (frequent roughening of outer surfaces, an admixture of coarse and medium-grained crushed stone, a relatively large quantity of thick-walled vessels resembling kitchen pottery) correspond to materials of this type from neighbouring settlement mesoregions (cf. Dzięgielewski 2010; Mazur - Gawlik 2011).

Also corresponding well to the above are the discoveries of two Scythian arrowheads representing forms dated to the period between the end of the seventh and the first quarter of the sixth century BCE, whose presence at this site, in the light of the latest research, ought to be correlated with the so-called Scythian invasions of Central Europe, and fall more or less at the end of the Early Iron Age (Ha D3; Chochorowski 2014, 41-42).

It must be acknowledged, however, that majority of the ceramic material obtained during the reported studies has a wider chronology within the Early Iron Age, and cannot be assigned exclusively to its latest period. It thus appears justified, at least at the present stage of analysis of these materials, to extend the dating of the settlement of this site from the phase $\mathrm{Ha} \mathrm{C}$ (perhaps from its latest part) to phase Ha D (again, it would appear, its final part). It is plausible that settlement at Ojców Castle should be at least partially synchronised with the recently discovered traces of a settlement from the younger period of the Early Iron Age in the region of the Pod Kazimierzem Hotel on the site of the former spa park in Ojców (Wojenka - Dzięgielewski 2016).

It remains unquestionable, however, that a large, stable settlement structure existed on the castle hill in Ojców during the Early Iron Age. This is proved not only by the features discovered there which indicate that buildings constantly existed at the site, but also by 
the numerous artefacts, including distinctive ones such as remains of salt-making ceramics as well as presence of ornaments and amorphous bronze lumps no doubt related to local, 'home' production.

The current state of research suggests that a settlement microregion of the Lusatian culture functioned in the area of the Jura, encompassing traces of varied activities within caves, focused around a central point, namely the settlement in Ojców, functioning in the Early Iron Age, that is, in the period Ha C-D (Wojenka 2016, 222).

The other nearest settlement sites are known in Iwanowice-Wysyłek (Kozłowski 1920; Górski 2018, fig. 1) located about $12 \mathrm{~km}$ east of the Ojców settlement (fig. 8). This is one of the earliest settlements of this culture in Lesser Poland. Another nearby open settlement site is site no. 3 in Będkowice, which is dated to the Late Bronze Age or Early Iron Age (Czarnowski 1910, 12-14; Jędrysik 2016, 56, 70-71). Further examples include the settlement complex consisting of four settlements and a cemetery at site 5 in Modlnica (Dzięgielewski 2015a), and the settlement and cemetery at site 2 in Modlniczka (Byrska-FudaliPrzybyta 2012), located approximately $10 \mathrm{~km}$ south of Ojców (fig. 8). Analysis of the artefact materials, and the small number of radiocarbon datings from those sites, confirm that they functioned in the younger Bronze Age and Early Iron Age, more specifically from Ha A2-B1 (Modlnica 5) and Ha B3 (Modlniczka 2), up till the end of the Lusatian culture phase (which fell in Ha D) and the start of the La Tène period (Byrska-Fudali-Przybyła 2012, 529-530; Dziegielewski 2015a, 116-118). At the same time, these sites document the continuity of settlement of the southern edges of the Ojców Jura by Lusatian culture communities starting from the period preceding the development of the classical Upper Silesian-Lesser Poland style (that is, from the Zofipole-Raciborsko phase; Gedl 1982b, 23-24, fig. 13) up to the latest developmental phase of that culture in western Lesser Poland, the Biskupice-Tyniec phase (Gedl 1982b, 28-29, fig. 13; Byrska-Fudali-Przybyła 2012, 530; Dzięgielewski 2015a, 117-118).

Similar settlement microregions of this type are known also from the pseudokarstic sandstone Český ráj region in Czech Republic, where cave sites are clustered close to small, short-lasting settlements at such open sites as Branžež and Nová Ves. Also considered a microregion is the neighbourhood of the Mužský massif, where the central point was a defensive settlement known today by the name Hrada (Peša 2006, 88). Compared with the Czech areas, the Ojców microregion is characterised by relatively numerous finds of a votive or sepulchral nature, and the frequent use of caves as provisional and short-lasting camps or shelters.

Given the existence of a permanent settlement in Ojców, one would expect also to find an open-air cemetery in the vicinity. Although the region has been relatively well researched, no such cemetery site has been found. The absence of any cemeteries in the karstic zone is also an interesting observation (fig. 8). They are present, however, adjacent to the settlements found on the edges of the Jura. Cemeteries are known in Rudawka (about $17 \mathrm{~km}$ to the south-west; Durczewski 1948a, fig. 1; 1948b, 86) and at Iwanowice-Klin Mountain (Kozłowski 1912) and Iwanowice-Wysyłek (fig. 8; Koztowski 1920). The necropolis in Iwanowice-Wysyłek is dated to Bronze Age period III and was connected with local settlements. The cemetery at Klin Mountain is dated to the Late Bronze Age and Early Iron Age (Durczewski 1948a, fig. 1; 1948b, 15; Kozłowski 1912). Other cemeteries close to the Sąspówka Valley are the sites in Brzezie (Gedl 1957), Modlniczka (site 2; cf. Byrska-Fudali-Przybyta 2012) and Modlnica (site 5; cf. Dzięgielewski 2015a), located about $10 \mathrm{~km}$ 
south or south-west of the Ojców settlement. The necropolises in Brzezie and Modlniczka functioned by the end of the Bronze Age and in the Early Iron Age, that is, in the Prokocim-Skotniki phase and possibly the Iwanowice-Klin phase (Gedl 1957; Byrska-FudaliPrzybyta 2012, 530). The cemetery at Modlnica is later and dates to the Ha D period and the start of the La Tène period, corresponding to the last phase of the development of the Lusatian culture in western Lesser Poland, the Biskupice-Tyniec phase (Dziegielewski 2015a, 102-103, fig. 79).

To date, only four grave features are known in the close vicinity of Ojców (fig. 8). In Sąspów (site 104) a single urn grave was discovered from the younger phase of the Early Iron Age (Liwoch - Wójcik - Wróbel 2015). A single cremation grave was also found in the same locality, but its contents have been lost (Rydzewski 2006, 476). In Będkowice (site 2; approximately $10 \mathrm{~km}$ from Ojców) there was discovered a single urn grave surrounded by stones, which may have been part of a larger cemetery destroyed by the mediaeval fortified settlement. This site can also be dated to the Early Iron Age (Ha C-D; Stotyhwo 1922; Jędrysik 2016, 45, 55, 66-70; 2018, 66). In the same area (Będkowice, site 34) a single skeletal grave was found, which can be dated to the end of the Bronze Age and the start of the Early Iron Age (Jędrysik 2016, 55; 2018, 66, 79, 82).

The absence of cemeteries in the karstic region may result from the present state of research or the destruction of Lusatian culture funeral sites by later settlement in the area, as well as by the erosive and accumulation effects of the numerous rivers there. Consideration should also be given to the possibility that only small cemeteries were established in this area, based on a 'clan' structure, attested by the presence of single graves. In this context, the finds discussed may be evidence of the use of caves as places of burial in the karstic areas. The find of Lusatian human remains in caves, representing a deviation from common practice in the Lusatian culture, poses new questions concerning the specific features of local settlement.

Even though caves were frequently used for ritual purposes in prehistoric times, such use of caves has not previously been recorded in Poland. The results of this study show that not only south of the Carpathians but also in Poland, in the karstic region of the Ojców Jura, caves and rockshelters were used for ritual purposes. Interestingly, the ritual and settlement uses of the cave sites in the Sąspówka Valley do not overlap, which may indicate the complexity of the use of landscape features by Lusatian groups. The caves with traces of ephemeral settlement use are located approximately 3-4 km from the Ojców Castle settlement, while all three above-mentioned caves with traces of ritual practices are located between that settlement and Tunel Wielki Cave, at distances from 15 up to 30 minutes walk from both sites.

\section{Conclusions}

The comparison of the analysed bones and artefacts from caves in the Sąspówka Valley, to similar finds in the close vicinity (including the Prądnik Valley) and to more extensive studies on the same subject conducted in the Czech Republic, Slovakia and Germany, suggests that the described sites form a kind of microregion concentrated around a permanent Lusatian settlement in Ojców. Most of the finds date to the end of the Bronze Age and to the Early Iron Age. Analysis of the available materials suggests that three of the studied 
cave sites can be considered as ritual sites. Bramka Rockshelter and Zbójecka Cave certainly contain skeletal burials from the end of the Bronze Age and the Early Iron Age. Ciasna Cave is the site of either a partial cremation burial or a votive deposit of vessels. Three other cave sites in the Sąspówka Valley containing Lusatian artefacts can be identified as short-term camps of groups of Lusatian people. Among them, only Tunel Wielki Cave carries traces of slightly more intensive use. The bronze arrowheads found there, dating from Lusatian times and bearing traces of striking, possibly against the cave wall, may be an evidence of hunting or of an act of violence committed here, taking place between Bronze Age period III and the Early Iron Age.

The presented results indicates the significant position of the Ojców microregion as the only area in modern Poland where caves are known to have been used for funeral and ritual purposes by people of the Lusatian culture. The study show the importance of radiocarbon dating in interpretation of Holocene settlement in cave sites; it can be used to verify the coherence of inventories of artefacts and bones often found within the same contexts and sediment layers. Only in rare cases does the Holocene sediments in caves separate into several layers (Krajcarz et al. 2020; Madeyska 1988; Wilczyński et al. 2020). In the great majority of cases we find a single humus layer of considerable thickness, containing artefacts deposited over the space of the past 10,000 years. At the same time, most of the cave inventories originates from research conducted over the past 150 years, which causes further difficulties in analysing the contexts of their discovery. Only the use of modern analytic methods makes it possible to recover the original context of these artefacts. Re-analysis of other cave sites in the Jura where Lusatian artefacts have been found will reveal if the ritual use of caves was limited to the area of the Sąspówka Valley, or was it a more widespread phenomenon.

This work was supported by the National Science Centre, Poland under Grant 2016/22/E/HS3/00486. We are grateful to the Ojców National Park for permitting archaeological fieldwork in the cave sites. We are grateful to the Archaeological Museum in Wroctaw for giving access to the Römer's collection. We would like to thank especially to Krzysztof Demidziuk, for his kind help with the collection and its history.

\section{References}

Almgren, O. 1923: Studien über nordeuropäischen Fibelformen der ersten nachchristlichen Jahrhunderte mit Berücksichtigung der provinzialrömischen und südrussischen Formen. Mannus-Bibliothek 32. Leipzig: Kabitzsch.

Andrzejewski, J. 1998: Nadkole 2: A cemetery of the Przeworsk culture in eastern Poland. Kraków: Instytut Archeologii i Etnologii PAN, Oddział w Krakowie.

Beckmann, Ch. 1969: Metallfingerringe der römischen Kaiserzeit im freien Germanien. Saalburg Jahrbuch $\mathrm{XXVI}$, 5-106.

Bergsvik, K. A. - Skeates, R. 2012: Caves in Context: the cultural significance of caves and rockshelters in Europe. Oxford - Oakville: Oxbow Books.

Brock, F. - Higham, T. - Ditchfield, P. - Ramsey, C. B. 2010: Current pretreatment methods for AMS radiocarbon dating at the Oxford Radiocarbon Accelerator Unit (ORAU). Radiocarbon 52, 103-112.

Bronk Ramsey, C. 2009: Bayesian analysis of radiocarbon dates. Radiocarbon 51, 337-360.

Bronk Ramsey, C. - Scott, M. - van der Plicht, H. 2013: Calibration for Archaeological and Environmental Terrestrial Samples in the Time Range 26-50 ka cal BP. Radiocarbon 55, 2021-2027. 
Büster, L. - Warmenbol, E. - Mlekuž, D. 2019: Between Worlds. Understanding Ritual Cave Use in Later Prehistory. Cham, Switzerland: Springer.

Byrska-Fudali, M. - Przybyta, M. M. 2012: Badania ratownicze na stanowisku 2 w Modlniczce, gm. Wielka Wieś. Raport 2007-2008. Vol. 1, Warszawa: NID, 509-553.

Chmielewski, W. 1988: Ogólna charakterystyka jaskiń Doliny Sąspowskiej pod względem występowania w nich żródeł archeologicznych. In: W. Chmielewski ed., Jaskinie Doliny Sąspowskiej. Tło przyrodnicze osadnictwa pradziejowego, Warszawa: Prace Instytutu Archeologii UW, 5-18.

Chochorowski, J. 2014: Scytowie a Europa Środkowa - historyczna interpretacja archeologicznej rzeczywistości. Materiały i Sprawozdania Rzeszowskiego Ośrodka Archeologicznego 35, 9-56.

Czajka, G. 2019: Źródła archeologiczne z holoceńskich nawarstwień sedymentu Jaskini Ciasnej z badań w latach 1969-70 i 2018. University of Warsaw (BA thesis).

Czarnowski, S. J. 1901: Jaskinia Borsucza nad rzeką Prądnikiem. Światowit 3, 75-84.

Czarnowski, S. J. 1902: Schroniska na Górze Okopy nad rzeką Prądnikiem pod Ojcowem. Materyały Antropologiczno-Archeologiczne i Etnograficzne 6, 13-26.

Czarnowski, S. J. 1903: Czaszki jaskiniowe z okolic rzeki Prądnika. Wszechświat 5, 73-75.

Czarnowski, S. J. 1904a: Czaszka z Jaskini Oborzysko Wielkie na lewym brzegu Prądnika pod Ojcowem. Światowit 5, 89-94.

Czarnowski, S. J. 1904b: Jaskinie wąwozu Korytanii nad rzeką Prądnikiem pod Ojcowem. Materyały Antropologiczno-Archeologiczne i Etnograficzne 7, 122-143.

Czarnowski, S. J. 1909: Szczęka i żuchwy ludzkie z jaskiń w okolicach Ojcowa na lewym brzegu rzeki Prądnika. Wszechświat 23, 353-355.

Czarnowski, S. J. 1910: Dolina Bętkowska i jej zabytki przeddziejowe. Warszawa: Wydawnictwo S. J. Czarnowskiego i Sp.

Czarnowski, S. J. 1911: Jaskinie i schroniska w Kopcowej Górze. Materyały Antropologiczno-Archeologiczne i Etnograficzne 12, 3-22.

Czarnowski, S. J. 1914: Jaskinie w skałach Ogrojca. Pamiętnik Fizjograficzny 22, 32-48.

Czarnowski, S. J. 1924: Jaskinie i Schroniska na Górze Koronnej na lewym brzegu Prądnika pod Ojcowem. Prace i Materiały Antropologiczno-Archeologiczne i Etnograficzne 3, 3-26.

Dowd, M. 2015: The Archaeology of caves in Ireland. Oxford - Philadelphia: Oxbow Books.

Durczewski, Z. 1948a: Grupa górnośląsko-małopolska kultury łużyckiej w Polsce, część I. Kraków: PAU.

Durczewski, Z. 1948b: Grupa górnośląsko-małopolska kultury łużyckiej w Polsce, część II. Kraków: PAU.

Dzięgielewski, K. 2010: Osada z młodszego odcinka wczesnej epoki żelaza na stanowisku 18 w Wojniczu, pow. Tarnów. In: J. Chochorowski ed.,Wojnicz 18 i 48, powiat Tarnów - osady z epoki brązu, żelaza i średniowiecza. Via Archaeologica. Źródła z badań wykopaliskowych na trasie autostrady A4 w Małopolsce, Kraków: Krakowski Zespół do Badań Autostrad, 205-268.

Dzięgielewski, K. 2015a: Zespół osadniczy z późnej epoki brązu i wczesnej epoki żelaza w Modlnicy. In: K. Dzięgielewski et al. eds., Modlnica, stan. 5. Od późnej epoki brązu po czasy średniowiecza. Via Archaeologica. Źródła z badań wykopaliskowych na trasie autostrady A4 w Małopolsce, Kraków: Krakowski Zespół do Badań Autostrad, 9-196.

Dzięgielewski, K. 2015b: Południowa rubież kultury pomorskiej i trajektorie łużycko-pomorskiej transformacji kulturowej w świetle badań w okolicach Krakowa. In: J. Chochorowski ed., Via Archaeologica. Od epoki brązu do czasów nowożytnych. Wybrane odkrycia i znaleziska, Kraków: Krakowski Zespół do Badań Autostrad, 81-113.

Dziegielewski, K. - Godlewski, P. 2009: Wschodnie oddziaływania kulturowe na terytorium zachodniej Małopolski we wczesnej epoce żelaza - źródła i interpretacje. In: S. Czopek - K. Trybała-Zawiślak eds., Tarnobrzeska kultura łużycka - źródła i interpretacje. Collectio Archaeologica Ressoviensis 11, Rzeszów: Fundacja Rzeszowskiego Ośrodka Archeologicznego, 191-225.

Galik, A. 1998: Gräber Tief im Fels des Tscheltschnigkogels? Hallstattzeitliche Menschen- und Tierknochen aus der Schachthöhle Durezza bei Villach, Kärnten. Geologisch-Paläontologische Mitteilungen 23, 61-66.

Gawlik, A. - Przybyła, M. S. 2005: Początki wczesnej epoki żelaza w Kotlinie Sandomierskiej. In: M. Kuraśeds, Archeologia Kotliny Sandomierskiej. Rocznik Muzeum Regionalnego w Stalowej Woli 4, Stalowa Wola: Muzeum Regionalne w Stalowej Woli, 313-352.

Gediga, B. - Józefowska, A. 2018a: Cmentarzysko wczesnej epoki żelaza w Domasławiu 10/11/12, powiat wrocławski. vol. I - Katalog. Wrocław: Fundacja Przyjaciół Instytutu Archeologii i Etnologii Polskiej Akademii Nauk. 
Gediga, B. - Józefowska, A. 2018b: Cmentarzysko wczesnej epoki żelaza w Domasławiu 10/11/12, powiat wrocławski. vol. II - Tablice, część 1. Wrocław: Fundacja Przyjaciół Instytutu Archeologii i Etnologii Polskiej Akademii Nauk.

Gedl, M. 1957: Cmentarzysko kultury łużyckiej we wsi Brzezie, powiat Kraków. Materiały Starożytne 2, 213-236.

Gedl, M. 1962: Kultura łużycka na Górnym Śląsku. Wrocław: Zakład Narodowy im. Ossolińskich Wydawnictwo PAN.

Gedl, M., 1975: Kultura łużycka. Kraków: Uniwersytet Jagielloński.

Gedl, M. 1982a: Cmentarzysko ze schyłku epoki brązu w Kietrzu. Wrocław etc.: Zakład Narodowy Imienia Ossolińskich.

Gedl, M. 1982b: Periodyzacja i chronologia kultury łużyckiej w zachodniej Małopolsce. In: M. Gedl ed., Południowa strefa kultury łużyckiej i powiązania tej kultury z południem, Kraków - Przemyśl: Uniwersytet Jagielloński. Instytut Archeologii, 11-33.

Golec, M. 2015: Prehistorie a historie jeskyně býči skály a blízkého okolí od neolitu po současnost. In. M. Oliva et al. eds., Jeskyně Býčí skála ve svých dějích a pradějích, Brno: Moravské zemské muzeum, 115-153.

Goslar, T. - Czernik, J. - Goslar, E. 2004: Low-energy 14C AMS in Poznań Radiocarbon Laboratory, Poland. Nuclear Instruments and Methods in Physics Research 223, 5-11.

Górski, J. 2018: Podkrakowska enklawa wczesnej kultury łużyckiej w świetle wyników najnowszych badań terenowych na trasie autostrady A4. Śląskie Sprawozdania Archeologiczne 60/1, 41-62.

Gutiérrez Cuenca, E. - Hierro Gárate, J. Á. - López Dóriga, I. - Martín Seijó, M. 2017: Fires in the Dark. Wood and Charcoal Analysis of the Early Medieval Funerary Deposits in the Cave of Riocueva (Cantabria, Spain). Estudos do Quaternário 16, 73-85.

Insoll, T. 2011: The Oxford Handbook of the Archaeology of Ritual and Religious. Oxford: Oxford University Press.

Jakubczyk, I. 2014: Die eingliedrigen Fibeln der Almgrens VI. Gruppe in der Przeworsk-Kultur-Fibeln des Typs A 158. Recherches Archeologiques. Nouvelle Serie 5-6, 113-218.

Jędrysik, J. 2016: Osadnictwo na Wyżynie Olkuskiej w epoce brązu i we wczesnej epoce żelaza. Kraków. Archiwum Instytutu Archeologii Uniwersytetu Jagiellońskiego (MA thesis).

Jędrysik, J. 2018: Rozwój i charakter osadnictwa na obszarze jury polskiej w późnej epoce brązu i wczesnej epoce żelaza. Śląskie Sprawozdania Archeologicze 60/1, 63-88.

Jiř́k, J. 2008: Ein Beitrag zur Erforschung der Besiedlung Ost- und Nordostböhmens während der späten Kaiser- und der frühen Völkerwanderungszeit. In: B. Niezabitowska-Wiśniewska et al. eds., The Turbulent Epoch. New materials from the Late Roman Period and the Migration Period I, Lublin: Wydawnictwo Uniwersytetu Marii Curie-Skłodowskiej, 157-177.

Kaczanowski, P. 1995: Klasyfikacja grotów broni drzewcowej kultury przeworskiej z okresu rzymskiego. Klasyfikacje zabytków archeologicznych I. Kraków: Instytut Archeologii i Etnologii PAN, Uniwersytet Jagielloński.

Kontny, B. - Savelâ, D. U. 2006: Voiny na rubeže mirov: vooruženie iż mogil'nika v Kilen-Balke. Materialy po Arheologii, Istorii i Ètnografii Tavrii XII, 129-160.

Kontny, B. - Szeliga, M. - Wojenka, M. - Kosiński, T. - Mueller-Bieniek, A. - Kot, M. 2021: A Unique Clay Rattle from Koziarnia Cave in Southern Poland. Archäologisches Korrespondenzblatt 51, 91-110.

Korczyńska, M. - Dzięgielewski, K. 2015: Uwarunkowania lokalizacji i relacje przestrzenne elementów zespołu osadniczego z epoki brązu i wczesnej epoki żelaza w Modlnicy w świetle analiz geoinformacyjnych. In: K. Dzięgielewski - M. Dzięgielewska - A. Sztyber eds., Modlnica, stan. 5 - od późnej epoki brązu po czasy średniowiecza, Via Archaeologica. Źródła z badań wykopaliskowych na trasie autostrady A4 w Małopolsce, Kraków: Krakowski Zespół do Badań Autostrad, 197-218.

Kot, M. - Gryczewska, N. - Berto, C. - Wojenka, M. - Szeliga, M. - Jaskulska, E. - Fetner, R. - Krajcarz, M. Wertz, K. - Zarzecka-Szubińska, K. - Krajcarz, M. T. - Moskal-del Hoyo, M. - Jakubczak, M. 2019: Thirteen cave sites: Settlement patterns in Sąspów Valley, Polish Jura. Antiquity 93, e30.

Kot, M. - Krajcarz, M. - Moskal-del Hoyo, M. - Gryczewska, N. - Wojenka, M. - Pyżewicz, K. - Sinet-Mathiot, V. Diakowski, M. - Fedorowicz, S. - Gasiorowski, M. - Marciszak, A. - Lipecki, G. - Mackiewicz, P. 2021: Chronostratigraphy of Jerzmanowician. New data from Koziarnia Cave, Poland. Journal of Archaeological Science: Reports 38, 103014.

Kot, M. - Wojenka, M. - Czajka, G. - Kontny, B. - Gryczewska, N. 2020: Post-Neolithic human occupation in Tunel Wielki Cave (southern Poland). Folia Quaternaria 88, 17-39. 
Kowalski, S. 1967: Wstępne wyniki badań archeologicznych w Jaskini Mamutowej prowadzonych w latach 1957-1964. Materiały Archeologiczne 8, 47-60.

Kozłowski, L. 1912: Cmentarzysko ciałopalne w Iwanowicach na Górze Klin (pow. Miechowski g. Kielecka). Światowit 10, 25-48.

Kozłowski, L. 1920: Cmentarzysko ciałopalne łużyckie z III-go okresu epoki brązowej na uroczysku Wysyłek w Iwanowicach (pow. miechowski). Wiadomości Archeologiczne 5, 43-55.

Krajcarz, M. T. - Szymanek, M. - Krajcarz, M. - Pereswiet-Soltan, A. - Alexandrowicz, W. P. - Sudot-Procyk, M. 2020: Shelter in Smoleń III - A unique example of stratified Holocene clastic cave sediments in Central Europe, a lithostratigraphic stratotype and a record of regional paleoecology. PLoS ONE 15/2: e0228546.

Lech, J. 2001: Archeologia Jury Ojcowskiej w zarysie. In: J. Lech - J. Partyka eds., Z archeologii Ukrainy i Jury Ojcowskiej, Ojców: OPN, 127-182.

Lech, J. - Partyka, J. 2006: Początek polskiej prehistorii w Jurze Ojcowskiej. In: J. Lech - J. Partyka eds., Z archeologii Ukrainy i Jury Ojcowskiej, Ojców: OPN, 55-83.

Ledogar, S. H. - Karsten, J. K. - Madden, G. D. - Schmidt, R. - Sokohatskyi, M. P. - Feranec, R. S. 2019: New AMS Dates for Verteba Cave and Stable Isotope Evidence of Human Diet in The Holocene Forest-Steppe, Ukraine. Radiocarbon 61/1, 141-158.

Liwoch, R. - Wójcik, I. - Wróbel, J. 2015: Grób z późnej fazy kultury łużyckiej z Sąspowa na Jurze Ojcowskiej. Prądnik. Prace i materiały muzeum im. prof. Władysława Szafera 25, 173-178.

Madeyska, T. 1988: Osady jaskiń i schronisk Doliny Sąspowskiej. In: W. Chmielewski eds., Jaskinie Doliny Sąspowskiej. Tło przyrodnicze osadnictwa pradziejowego. Warszawa: Prace Instytutu Archeologii UW, 77-173.

Madyda-Legutko, R. 1986: Die Gürtelschnallen der römischen Kaiserzeit und der frühen Völkerwanderungszeit im mitteleuropäischen Barbaricum, BAR International Series 360, Oxford: Archeopress.

Magomedov, B. V. 2015: Keramičeskie prâslica černâhovskoj kul'tury. Kiev: IA NANU.

Mazur, M. - Gawlik, A. 2011: Cmentarzysko i osada z młodszej, późnej epoki brązu i wczesnej epoki żelaza na stanowisku w tętowicach. In: M. Mazur - A. Gawlik eds., Wyniki ratowniczych badań wykopaliskowych na stanowisku 11 w Łętowicach, pow. tarnowski, woj. małopolskie (AZP 103-65/45), vol. I. Unpublished typescript, Kraków, 18-44.

Mq̨czyńska, M. - Rook, E. 1972: Materiały z Jaskini Wierzchowskiej Górnej w zbiorach Muzeum Archeologicznego w Krakowie. Materiały Archeologiczne 13, 113-150.

Młodkowska-Przepiórowska, I. 1995: Praktyki wierzeniowe ludności grupy górnośląsko-małopolskiej. Śląskie Prace Prahistoryczne 4, 113-121.

Moyes, H. 2014: Sacred Darkness. A Global Perspective on the Ritual Use of Caves, Boulder: University Press of Colorado, 1-11.

Mycielska, R. - Rook, E. 1965: Materiały z Jaskini w Okopach Wielkiej, Dolnej, pow. Olkusz. Materiały Archeologiczne 6, 145-179.

Olszyński, M. 1871: Wycieczka do grot Ojcowskich. Kłosy 13, 381-382.

O'Regan, H. J. - Bland, K. - Evans, J. - Holmes, M. - McLeod, K. - Philpott, R. - Smith, I. - Thorp, J. - Wilkinson, D. M. 2020: Rural Life, Roman Ways? Examination of Late Iron Age to Late Romano-British Burial Practice and Mobility at Dog Hole Cave, Cumbria. Britannia 51, 83-116.

Orschiedt, J. 2012: Cave burials in prehistoric Central Europe. In: K. A. Bergsvik - R. Skeates eds., Caves in Context: the cultural significance of caves and rockshelters in Europe, Oxford-Oakville: Oxbow Books, 212-224.

Ossowski, G. 1884: Sprawozdanie z badań paleo-etnologicznych w jaskiniach okolic Ojcowa dokonanych w r. 1883. Zbiór Wiadomości do Antropologii Krajowej 8, 35-86.

Ossowski, G. 1885a: Jaskinie okolic Ojcowa pod względem paleoetnologicznym, Kraków: Uniwersytet Jagielloński.

Ossowski, G. 1885b: Sprawozdanie z badań paleo-etnologicznych w jaskiniach okolic Ojcowa dokonanych w roku 1884. Zbiór Wiadomości do Antropologii Krajowej 9, 3-13.

Ossowski, G. 1886: Sprawozdanie z badań paleoetnograficznych w jaskiniach okolic Ojcowa, dokonanych w roku 1886. Zbiór Wiadomości do Antropologii Krajowej 10, 13-31.

Partyka, J. 1992: Ojców i archeologia w latach 1871-1924. In. J. Lech, J. Partyka, eds., Prof. Stefan Krukowski (1890-1982). Działalność archeologiczna i jej znaczenie dla nauki polskiej, Ojców: OPN, 71-86.

Parzinger, H. - Nekvasil, J. - Barth, F. 1995: Die Býčí skála-Höhle - Ein Hallstattzeitlicher Höhlenopferplatz in Mähren. Mainz: Verlag Philipp von Zabern. 
Peša, V. 2006: Využívání jeskyní v mladší době bronzové až halštatské ve vybraných oblastech střední Evropy. Památky archeologické 97, 47-132.

Peter-Röcher, H. 1998: Die Býčí skála-Höhle in Mähren - Opfer, Ahnenkult und Totenritual in der Hallstattzeit. Das Altertum 44, 3-30.

Peterson, R. 2019: Neolithic cave burials. Agency, structure and environment, Manchester: Manchester University Press.

Pilcicka-Ciura, H. 1995: Stanowisko archeologiczne w schronisku skalnym Bramka w Ojcowie, Warszawa (MA thesis).

Quast, D. 2013: Ein kleiner Goldhort der jüngeren römischen Kaiserzeit aus Černivci (ehem. Czernowitz / Cernăuți) in der westlichen Ukraine nebst einigen Anmerkungen zu goldenen Kolbenarmringen. In: M. Hardt - O. Heinrich-Tamáska eds., Macht des Goldes, Gold der Macht. Herrschafts- und Jenseitsrepräsentation zwischen Antike und Frühmittelalter im mittleren Donauraum. Akten des 23. Internationalen Symposiums der Grundprobleme der frühgeschichtlichen Entwicklung im mittleren Donauraum, Tengelic 16.-19.11.2011, Weinstadt: Verlag Bernhard Albert Greiner, 171-186.

Riel-Salvatore, J. - Gravel-Miguel, C. 2013: Upper Palaeolithic Mortuary Practices in Eurasia. In: L. Nilsson Stutz - T. Tarlow eds., The Oxford Handbook of the Archaeology of Death and Burial, Oxford: Oxford University Press, 304-346.

Römer, F. 1883: Die Knochenhöhlen von Ojcow in Polen. Palaeontographica 29, 193-233.

Römer, F. 1884: The Bone Caves of Ojców (Poland). London: Spottiswoode and Co.

Rydzewski, J. 2006: Jura Ojcowska w czasach kultury łużyckiej. In: J. Lech - J. Partyka eds., Jura Ojcowska w pradziejach I w początkach państwa polskiego, Ojców: OPN, 475-487.

Rook, E. 1963: Materiały z Jaskini Bębłowskiej Dolnej. Materiały Archeologiczne 4, 335-346.

Rook, E. 1964: Materiały z Jaskini Oborzysko Małe. Materiały Archeologiczne 5, 193-210.

Rook, E. 1980: Osadnictwo neolityczne w jaskiniach Wyżyny Krakowsko-Częstochowskiej. Materiały Archeologiczne 20: 5-130.

Schauer, P. 1981: Urnenfelderzeitliche Opferplatze in Hohlen und Felsspalten. In: H. Lorenz ed., Studien zur Bronzezeit. Festschrift fur W. A. von Brunn. Mainz a. Rhein: von Zabern, 403-418.

Scheuer, L. - Black, S. 2000: Developmental Juvenile Osteology. San Diego: Academic Press.

Schuster, J. 2016: Masse - Klasse - Seltenheiten. Kaiserzeitliche und völkeranderungszeitliche Detektorfunde der Jahre 2006-2014 aus Schleswig-Holstein. Archäologische Nachrichten aus Schleswig-Holstein Sonderheft. Schleswig: Archäologisches Landesamt Schleswig-Holstein.

Skripkin, A. 2003: Östliche und westliche Neuerungen in der materiellen Kultur der Sarmaten der europäischen Steppen in der ersten Jahrhunderten n. Chr. In: C. von Carnap-Bornheim eds., Kontakt Kooperation - Konflikt. Germanen und Sarmaten zwischen dem 1. und dem 4. Jahrhundert nach Christus, Neumünster: Wachholtz, 9-18.

Stasiak, M. 1994: Ceramika z cmentarzyska kultury przeworskiej w Opoce. Kultura przeworska 2. Lublin: Wydawnictwo Uniwersytetu Marii Curie-Skłodowskiej.

Stotyhwo, K. 1922: Sprawozdanie z poszukiwań przedhistorycznych na Sokolej Skale w Bętkowicach. Archiwum Nauk Antropologicznych Towarzystwa Naukowego Warszawskiego, 3, Dział C: Archeologia 1, $1-6$.

Stuhlfauth, A. 1951: Fundberichte zur Vor- und Frühgeschichte im Gebiet der Fränkischen Alb. Archiv für die Geschichte von Oberfranken 35/3, 121-159.

Suder, W. 2000: Osada kultury łużyckiej na stanowisku Iwanowice-Babia Góra II. Sprawozdania Archeologiczne 52, 171-2019.

Svoboda, J. - Van der Plicht, J. - Vlček, E. - Kuželka, E. 2004: New radiocarbon datings of human fossils from caves and rockshelters in Bohemia (Czech Republic). Anthropologie XLII/2, 161-166.

Szelerewicz, M. - Górny, A. 1986: Jaskinie Wyżyny Krakowsko-Wieluńskiej. Kraków - Warszawa: PTTK 'Kraj'.

Szter, I. 2011: Martin Jahn - eine biographische Skizze. Nachrichtenblatt für deutsche Vorzeit 19 (1943), 168-175.

Tejral, J. 1992: Einige Bemerkungen zur Chronologie der späten römischen Kaiserzeit in Mitteleuropa. In: K. Godłowski - R. Madyda-Legutko eds., Probleme der relativen und absoluten Chronologie ab Latènezeit bis zum Frühmittelalter. Kraków: Secesja, 227-248.

Tempelmann-Mqczyńska, M. 1985: Die Perlen der römischen Kaiserzeit und der frühen Phase der Völkerwanderungszeit im mitteleuropäischen Barbaricum. Mainz am Rhein: Verlag Philipp von Zabern.

Trachsel, M. 2004: Untersuchungen zur relativen und absoluten Chronologie der Hallstattzeit, Teil 1. Universitätsforschungen zur Prähistorischen Archäologie 104. Bonn: Habelt 
Valde-Nowak, P. - Stefański, D. - Szczepanek, A. 2018: A Neolithic Child Burial from Ciemna Cave in Ojców National Park, Poland. In. D. H. Werra - M. Woźny eds., Between History and Archaeology. Papers in Honour of Jacek Lech, Oxford: Archaeopress, 279-288.

Walanus, A. - Goslar, T. 2009: Datowanie radiowęglowe. Kraków: Wydawnictwo AGH.

Walter, D. 1985: Thuringer Höhlen und ihre holozänen Bodenaltertumer. Weimarer Monographien zur Ur- und Frühgeschichte 14. Weimar.

Wilczyński, J. - Krajcarz, M. T. - Moskal-del Hoyo, M. - Alexandrowicz, W. P. - Miękina, B. - Pereswiet-Soltan, A. - Wertz, K. - Lipecki, G. - Marciszak, A. - Lõugas, L. - Gradziński, M. - Szczepanek, A. - Zastawny, A. - Wojenka, M. 2020: Late Glacial and Holocene paleoecology and paleoenvironmental changes in the northern Carpathians foreland : the Żarska Cave (southern Poland) case study. Holocene 30/6, 905-922.

Wilczyński, J. - Wojenka, M. - Wojtal, P. - Szczepanek, A. - Sobieraj, D. 2012: Human occupation of the Borsuka Cave (southern Poland) - From Upper Paleolithic to the Post-Medieval Period. Eurasian Prehistory 9/1-2, 77-91.

Wojenka, M. 2012: Jaskinie Wyżyny Krakowsko-Częstochowskiej w średniowieczu. Wstęp do problematyki. Prądnik. Prace i materiały muzeum im. prof. Władysława Szafera 22, 7-43.

Wojenka, M. 2016: Sprawozdanie z badań wykopaliskowych przeprowadzonych na zamku w Ojcowie w latach 2006-2014. Prądnik. Prace i materiały muzeum im. prof. Władysława Szafera 26, 199-224.

Wojenka, M. - Dzięgielewski, K. 2016: Pozostałości osady z wczesnej epoki żelaza i XIX-wiecznych początków uzdrowiska: Wyniki nadzoru archeologicznego na terenie dawnego parku zdrojowego w Ojcowie. Prądnik. Prace i materiały muzeum im. prof. Władysława Szafera 26, 225-240.

Wojenka, M. - Krajcarz, M. T. - Szczepanek, A. - Wilczyński, J. 2017: Sprawozdanie z badań wykopaliskowych przeprowadzonych w Jaskini Tunel Wielki w Wąwozie Koziarnia w 2016 roku. Prądnik. Prace i materiały muzeum im. prof. Władysława Szafera 27, 147-168.

Zawisza, J. 1874: Jaskinia Mamutowa w Dolinie Wierzchowskiej w okolicy Ojcowa i Krakowa położona. Wiadomości Archeologiczne 2, 5-23.

Zyzman, A. 2009: Obiekty bez kości na cmentarzyskach grupy tarnobrzeskiej kultury łużyckiej. In: S. Czope K. Trybała-Zawiślak eds., Tarnobrzeska kultura łużycka - źródła i interpretacje, Rzeszów: Fundacja Rzeszowskiego Ośrodka Archeologicznego, 303-310.

\footnotetext{
MAtGORZATA KOT, Faculty of Archaeology, University of Warsaw, Krakowskie Przedmieście 26/28, PL-00-927 Warsaw, ORCID 0000-0001-5277-0283; m.kot@uw.edu.pl GRZEGORZ CZAJKA, Faculty of Archaeology, University of Warsaw, Krakowskie Przedmieście 26/28, PL-00-927 Warsaw, ORCID 0000-0002-1311-1274; g.czajka@student.uw.edu.pl

ELŻBIETA JASKULSKA, Faculty of Archaeology, University of Warsaw, Krakowskie Przedmieście 26/28, PL-00-927 Warsaw, ORCID 0000-0001-8786-5602; ejaskulska@uw.edu.pl BARTOSZ KONTNY, Faculty of Archaeology, University of Warsaw, Krakowskie Przedmieście 26/28, PL-00-927 Warsaw, ORCID 0000-0003-3627-046X; bdkontny@uw.edu.pl ADRIAN MARCISZAK, Department of Paleozoology, University of Wrocław, Sienkiewicza 21, PL-50-335 Wrocław, ORCID 0000-0002-1472-6553; adrian.marciszak@uwr.edu.pl MICHAŁ MAZUR, Institute of Archaeology, Jagiellonian University, Gołębia 11, PL-31-007 Cracow, Poland, ORCID 0000-0002-6745-837X; mihal.mazur@uj.edu.pl MARCIN SZELIGA, Institute of Archaeology, Maria Curie-Skłodowska University, PI. M. Curie-Skłodowskiej 4, PL-20-031 Lublin, Poland, ORCID 0000-0002-5185-073X; marcin.szeliga@poczta.umcs.lublin.pl MICHAŁ WOJENKA, Institute of Archaeology, Jagiellonian University, Gołębia 11, PL-31-007 Cracow, Poland, ORCID 0000-0002-6205-5627; michal.wojenka@uj.edu.pl
} 